S. Galdenzi, F. Cocchioni, G. Filipponi, L. Morichetti, S. Scuri, R. Selvaggio, and M. Cocchioni - The sulfidic thermal caves of Acquasanta Terme (central Italy). Journal of Cave and Karst Studies, v. 72, no. 1, p. 43-58. DOI: 10.4311/jcks2008es0056

\title{
THE SULFIDIC THERMAL CAVES OF ACQUASANTA TERME (CENTRAL ITALY)
}

\author{
Sandro Galdenzi ${ }^{*}$, Filippo Cocchioni², Giampaolo FilipPoni ${ }^{3}$, Luciana Morichettr ${ }^{2}$, \\ Stefania Scuri ${ }^{2}$, Rosario Selvaggio ${ }^{3}$, and Mario Cocchioni ${ }^{2}$
}

\begin{abstract}
The caves of Acquasanta Terme (central Italy) open at the core of a wide anticline, in the valley of the Tronto River. Cave development is due to the rise of sulfidic thermal water flowing through a thick marine limestone sequence, overlain by thick, lowpermeability formations. Some minor caves are developed in the terraced travertines deposited by the thermal water, but the major caves are developed in marine limestone in the small gorge of the Rio Garrafo stream, a tributary of the Tronto River. These caves have a rising pattern, due to the past flow of thermal water toward the surface. The deepening of the Tronto River Valley lowered the regional water table, perching the Rio Garrafo stream $\sim 50 \mathrm{~m}$ above the thermal groundwater. At present, surface water sinks through the pre-existing karst passages to reach the thermal water flowing in the lower parts of the caves. Where these waters mix, rapid corrosion of the walls through sulfuric acid speleogenesis occurs. Annual temperature and chemistry monitoring of the cave water showed that freshwater contributes up to $45 \%$ of the volume at the water table. Dilution events are associated with falling water temperature, which ranges between $44^{\circ} \mathrm{C}$ and $32^{\circ} \mathrm{C}$. At the main spring, $2 \mathrm{~km}$ downstream, groundwater dilution was higher resulting in lower temperatures $\left(32^{\circ} \mathrm{C}-21^{\circ} \mathrm{C}\right)$ and salinity. The periods of high freshwater dilution correspond with a lowering of $\mathrm{pH}$ in the phreatic water and with the release of $\mathrm{H}_{2} \mathrm{~S}$ and $\mathrm{CO}_{2}$ to the cave atmosphere. In the thermal zones, the concentration of $\mathrm{H}_{2} \mathrm{~S}$ increased from 40 to over $240 \mathrm{ppm}$, while $\mathrm{CO}_{2}$ increased from $0.44 \%$ to $2.7 \%$. These data evidence the influence of sinking surface water on the cave environment and speleogenesis.
\end{abstract}

\section{INTRODUCTION}

The thermal caves of Acquasanta Terme represent a window on active sulfuric acid speleogenesis. Some caves in the area have been known since ancient times due to their large entrances and easy accessibility. A modern exploration, however, began only after World War II when the management of the thermal baths invited the speleologist of the Società Adriatica di Scienze Naturali (Trieste, Italy) to explore the area some tens of years later than in nearby zones. The speleologist of the Società Adriatica, helped by the Gruppo Speleologico Marchigiano from Ancona (G.S.M.), explored the siphon in the Acquasanta cave, which feeds the spring and some short caves in the narrow limestone outcrops of the nearby Rio Garrafo Valley. Based on these explorations, Maucci (1954) recognized the possibility of a hydraulic connection between the caves in the Rio Garrafo Valley and the thermal spring. He believed that the role of the thermal water was only secondary, because in his opinion, the rising thermal water used a preexisting cave to reach the surface and caused only minor chemical alteration of the cave walls. Even if this interpretation is clearly related to the ideas of the period, Principi (1931) had already proposed, based on his study of the nearby thermal sulfidic Triponzo spring, that sulfidic water causes cave formation due to sulfuric acid production, followed by the replacement of limestone with gypsum that is easily removed by flowing water.
New explorations were carried out by speleologists of the G.S. CAI Teramo, who explored the Grotta Fredda during the 1970s, and by the members of the G.S.M. CAI di Ancona and the Associazione Speleologica Acquasantana, who explored the Grotta Lunga and the Grotta Nuova in the 1980s. Cave explorers in the Grotta Lunga and Grotta Nuova reached some active thermal zones below the valley of the Rio Garrafo. Since these explorations, the speleologists have continuously explored the area even though a complete survey of the explored passages is not still available. At present, the total extension of the cave passages exceeds $3000 \mathrm{~m}$ in length.

New ideas about the cave origins were discussed in 1994 at the XVII National Congress of Speleology, where Galdenzi described the general features and setting of the caves, attributing their development to the mixing of this rising sulfidic water with the descending freshwater infiltrating from the Rio Garrafo, mainly in phreatic conditions. These ideas, published in 1997, were then summarized in a paper on the sulfidic caves of central Italy (Galdenzi and Menichetti, 1995). In a subsequent paper,

\footnotetext{
* Corresponding author.

${ }^{1}$ Viale Verdi 10,60035 Jesi, Italy. galdenzi.sandro@tiscali.it

${ }^{2}$ Dipartimento di Medicina Sperimentale e Sanità Pubblica, Università di Camerino, Italy.filippo.cocchioni@unicam.it, luciana.morichetti@unicam.it, stefania.scuri@, unicam.it, mario.cocchioni@unicam.it

${ }^{3}$ Associazione Speleologica Acquasantana, Frazione Santa Maria, 63041 Acquasanta Terme, Italy. geotritone1@libero.it
} 


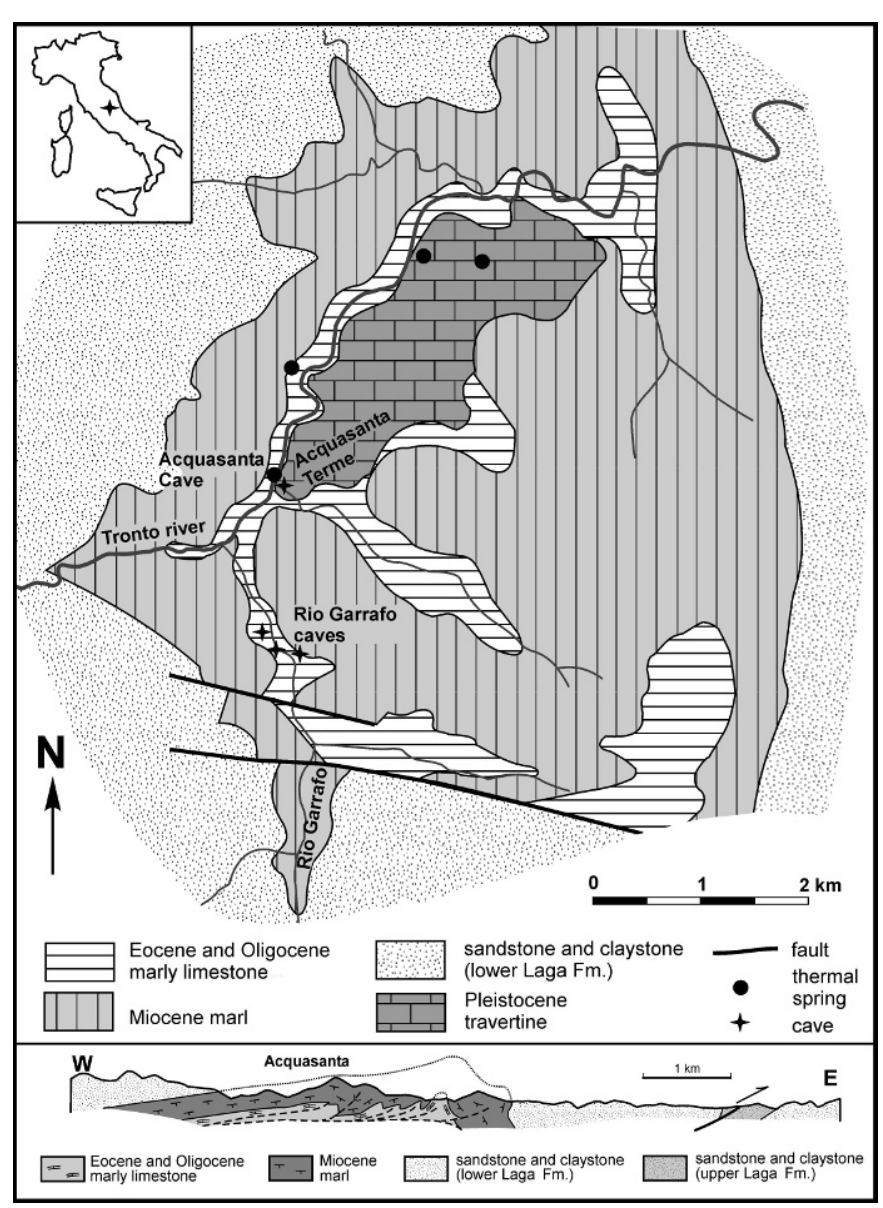

Figure 1. Geologic map of the study area. Geologic section after Scisciani and Montefalcone (2005), simplified.

Galdenzi (2001) compared geomorphic characteristics and environmental conditions of the Acquasanta caves with those of the Frasassi caves and Movile Cave (Romania). More recently, research on the microbiota of the thermal zone of the cave has begun (Jones et al., 2006). In this paper, we present new data on the air and water characteristics and discuss the present and past conditions of the cave development.

\section{Geologic Setting}

\section{Location and Climate}

The karst area of Acquasanta Terme is on the eastern side of the Apennine Mountains, $40 \mathrm{~km}$ from the Adriatic Sea, in the southern Marche region (central Italy). The caves open in the deep transverse valley that Tronto River cuts in the northern termination of the Laga Mountains (Fig. 1). A mountainous landscape prevails, with altitudes ranging between $300 \mathrm{~m}$ at the bottom of the valley to about $1100 \mathrm{~m}$ in the surrounding mountains. The climate is Apenninic sub-continental, with an annual average temperature of about $12^{\circ} \mathrm{C}$ and an average rainfall of about $950 \mathrm{~mm} \mathrm{yr}^{-1}$ in the valley (Nanni, 1991). Precipitation generally reaches a maximum in autumn and spring and thunderstorms are frequent at the end of summer. In the winter, snowfall is common in the mountains where the thawing occurs at the beginning of the spring.

\section{Regional Geology}

The Appennines consist of a sequence of anticlines overthrust to the east. The folds originated during the late Miocene and the Pliocene during a tectonic compressive phase that caused the uplift and emersion (for details on the regional geology, see Regione Marche, 1991, and Crescenti et al., 2004, with references).

The lower part of the stratigraphic sequence includes a 2000-m-thick Late Triassic evaporitic sequence. Jurassic, Cretaceous, and Paleogene deposits are 2000-m-thick and mainly carbonates. In the Oligocene and Miocene, marl deposition prevailed in the whole area. Messinian (Late Miocene) deposits consist of a foredeep turbiditic siliciclastic sequence (Laga Formation, over 3000-m-thick), where thick beds of sandstone alternate with thinner mudstone. The very fast sedimentation rate overprinted the effects of the Messinian salinity crisis that occurred in the Mediterranean Basin, and as a result, only a few gypsum-arenitic turbidites record evaporitic conditions in the source area. The area emerged over sea level during the Pliocene; after this event, a low relief energy paleosurface developed. At the end of early Pleistocene, the river entrenched the present valleys into the old erosional surface.

\section{Site Geology}

The karst area is located in the core of the wide anticline of Acquasanta Terme, constituted by Miocene marl, sandstone, and mudstone (Fig. 1). The thick marly and terrigenous Oligocene and Miocene sequence outcrops everywhere and only in the core of the anticline the top of the underlying limestone sequence is exposed in the valley of the Rio Garrafo, a tributary of the Tronto River.

A gently dipping bedding prevails in the core of the anticline even if some detachment levels occur (Marsili and Tozzi, 1995). On the eastern limb, the bedding inclination increases rapidly and the Acquasanta Anticline overthrusts the Miocene sandstone of the Laga Formation (Fig. 1) with a throw of up to $2 \mathrm{~km}$ (Scisciani and Montefalcone, 2005). The Acquasanta anticline, $10 \mathrm{~km}$ to the west, lies on the footwall of the Sibillini Mountain Thrust, a regional structure that carries the Mesozoic limestone above the Messinian sequence.

Continental deposits in the Acquasanta zone form a diffuse, thin cover of colluvial and detrital slope deposits and, in the main valleys, some terraced sand and gravel deposits. The most significant terrestrial unit, however, is the large plate of travertine along the right bank of the Tronto River, whose deposition was related to the rise of sulfidic water from a confined aquifer (Boni and Colacicchi, 1966). Both alluvium and travertine deposition were influenced by climate changes between glacial and interglacial periods that caused alternating depositional and 
erosional periods in the river valley. More recently, Farabollini et al. (2001) related the travertine deposition to revegetation in the mountains at the beginning of interglacials. The increase of $\mathrm{CO}_{2}$ content in the seepage water that reaches the confined aquifer should have favored the travertine deposition. Madonna et al. (2005) described the physical and petrographic characteristics of travertine, linking their depositional setting to the rise of thermal water.

\section{LiTHOLOGY}

The lowest stratigraphic unit that outcrops locally is the Scaglia Rossa Formation (Cenomanian - Middle Eocene). This unit has variable regional characteristics and its thickness can vary between 200 and $500 \mathrm{~m}$. In the area, only the upper part of the Scaglia Rossa outcrops, and consists of reddish limestone and marly limestone that is well stratified in layers of $\sim 20 \mathrm{~cm}$. The top of this unit also contains cherty beds, while in its lower levels (not outcropping in the area), a gradual decrease of the marly content occurs. At depth, below the Scaglia Rossa Formation, the carbonate sequence continues with other limestone and cherty limestone formations that are interbedded with two main marl levels (up to $50 \mathrm{~m}$ thick). This mainly permeable sequence reaches $1500-2000 \mathrm{~m}$ in thickness and outcrops widely in the Umbria-Marche Apennines where it hosts the most important aquifers.

The overlying Scaglia Variegata (Middle Eocene - Upper Eocene) is a $50 \mathrm{~m}$ thick unit, which represents the transition between the Scaglia Rossa and the Oligocene marls. It is a cherty and marly limestone with alternating whitish and reddish color. In the Acquasanta area, this unit has been karstified.

The carbonate content further decreases in the Oligocene Scaglia Cinerea, a marl unit up to 200-m-thick. This Formation and the overlying Miocene marly units (Bisciaro, Marne con Cerrogna, Marne a Pteropodi) constitute the most important regional aquiclude, with a total thickness that exceeds $500 \mathrm{~m}$.

The Messinian Laga Formation outcrops everywhere in the surrounding mountains. This unit alternates thick turbiditic sandstone and clay and silt beds to create characteristic steps in the mountainsides. Groundwater flow is possible in the permeable sandy zones where small springs can occur.

The pure, porous limestone of the Pleistocene travertine represents a further karstified unit. These deposits reach a thickness of tens of meters and extend for several $\mathrm{km}^{2}$ at three different elevations located along the right bank of the Tronto River (Fig. 2; Boni and Colacicchi, 1966).

\section{HydRogeOLOGY}

The Tronto River and its tributaries have an irregular discharge due to the low permeability of their basins and to the contribution of snow thawing from the mountains. The groundwater in the area consists mainly of the thermal sulfidic water that rises from the capped aquifer hosted in the carbonate sequence. The most important spring in the area is in the village of Acquasanta Terme at the outflow of the Acquasanta Cave. This spring has a discharge that seasonally varies between 60 and $220 \mathrm{~L} \mathrm{~s}^{-1}$ (Perrone, 1911) and is located in the right bank of the Fiume Tronto stream (Fig. 3), near the core of the anticline in the Scaglia Cinerea formation.

Some further minor thermal springs are downstream near the river bed and also at higher altitude in the right side of the valley. One spring is located at the bottom of a large shaft in the terraced travertine deposits, $\sim 100 \mathrm{~m}$ above the river bed. The thermal groundwater can be reached also in the lower sections of the caves in the Rio Garrafo Valley.

The groundwater flowpath in the area is heavily influenced by the geologic setting. The prevailing lowpermeability formations that cap the thermal aquifer reduce the local recharge of the aquifer. Only in the Rio Garrafo Gorge, sinking stream water directly reaches the thermal water inside caves.

The chemistry of the spring water, enriched in $\mathrm{Cl}^{-}$and $\mathrm{Na}^{+}$, and the isotopic data (Zuppi et al., 1974) indicate the co-existence of a deep circuit involving water with a probable meteoric origin that rises and dilutes with a variable amount of cold water coming from fast surface circuits. The high salt content could be acquired flowing through the underlying Triassic evaporitic sequence at the core of the anticline or through Messinian gypsum in the footwall of the Acquasanta thrust (Nanni and Vivalda, 2005). Madonna et al. (2005), however, hypothesize a contribution of volcanic fluids to explain the water chemistry. The high temperature of the geothermal field of Acquasanta could also be due to a magmatic intrusion at the core of the anticline (Madonna et al., 2005), that, however, is not reported by most authors who have analyzed the deep structure of the anticline (Scisciani and Montefalcone 2005, with references).

\section{The Karst Area of Acquasanta Terme}

Surface karst phenomena are not well developed in the area where mainly siliciclastic or marly formations prevail. The widest limestone outcrop, the large travertine plate, is generally covered by colluvial deposits or soils and only small scale corrosion features develop in narrow zones where the limestone surface is directly exposed to meteoric water. Deep karst, however, has a greater development in a hypogenic setting and thirteen caves are known with a total length that exceeds $3 \mathrm{~km}$. Only a few caves are known in the large travertine deposits, and the major caves (Grotta Fredda, Grotta Nuova, and Grotta Lunga) developed in the small limestone outcrop of the Meso-Cenozoic marine sequence in the Rio Garrafo Valley.

\section{The Travertine Caves \\ Grotta di Acquasanta}

The Grotta di Acquasanta (length: $\sim 300 \mathrm{~m}$ ) is the main cave in the travertine. It is a wide chamber flooded by sulfidic water that directly feeds the main thermal spring 


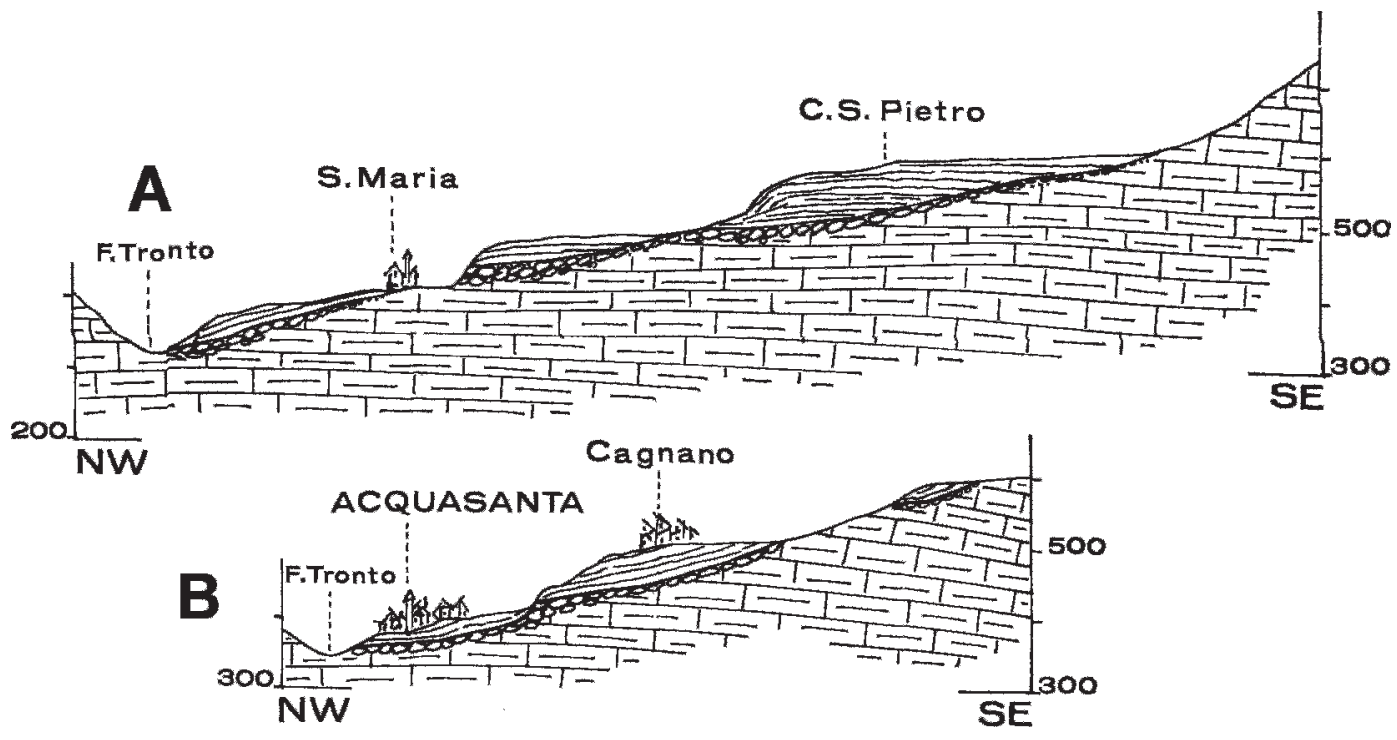

Figure 2. Geologic sections in the central (A) and south (B) part of the travertine deposit (after Boni and Colacicchi, 1966).

through a brief active passage. This cave developed at the base of the travertine body where it overlies the Oligocene marl formation of Scaglia Cinerea (Fig. 2). The bottom of the lake in the cave is covered by soft organic mud and water rises to the lake through a highly inclined passage explored up to 12-m-deep (Maucci, 1954). Gas release causes the corrosion of walls and roofs in the whole cave. The thermal stream water is causing carbonate deposition near the spring. At present, the cave is not directly utilized for thermal baths and water in the nearby commercial bath is derived from a drilled well.

\section{The Rio Garrafo Caves}

The most important caves are located in a small area in the lower part of the Rio Garrafo Valley, where the stream entrenches in a narrow canyon inside the limestone sequence (Fig. 4). Rio Garrafo is a small tributary of the Tronto River with a recharge basin almost entirely in the Laga Formation at altitudes ranging from $300 \mathrm{~m}$ to $2050 \mathrm{~m}$. Gravel deposits, coming from the upper part of the basin, fill the bottom of the gorge near the caves entrances, while in the lower part of the canyon, the stream is still eroding the bedrock.

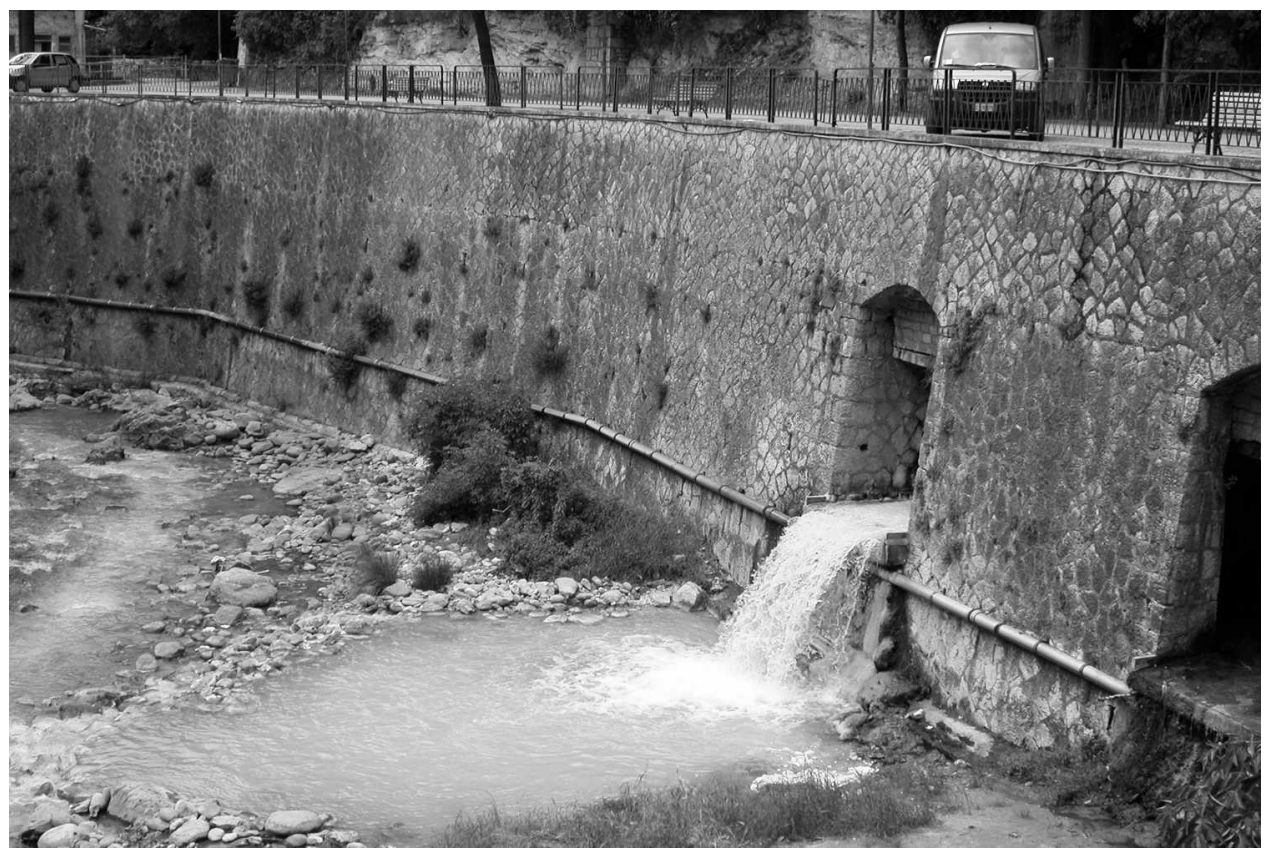

Figure 3. The thermal spring of Acquasanta Terme. 


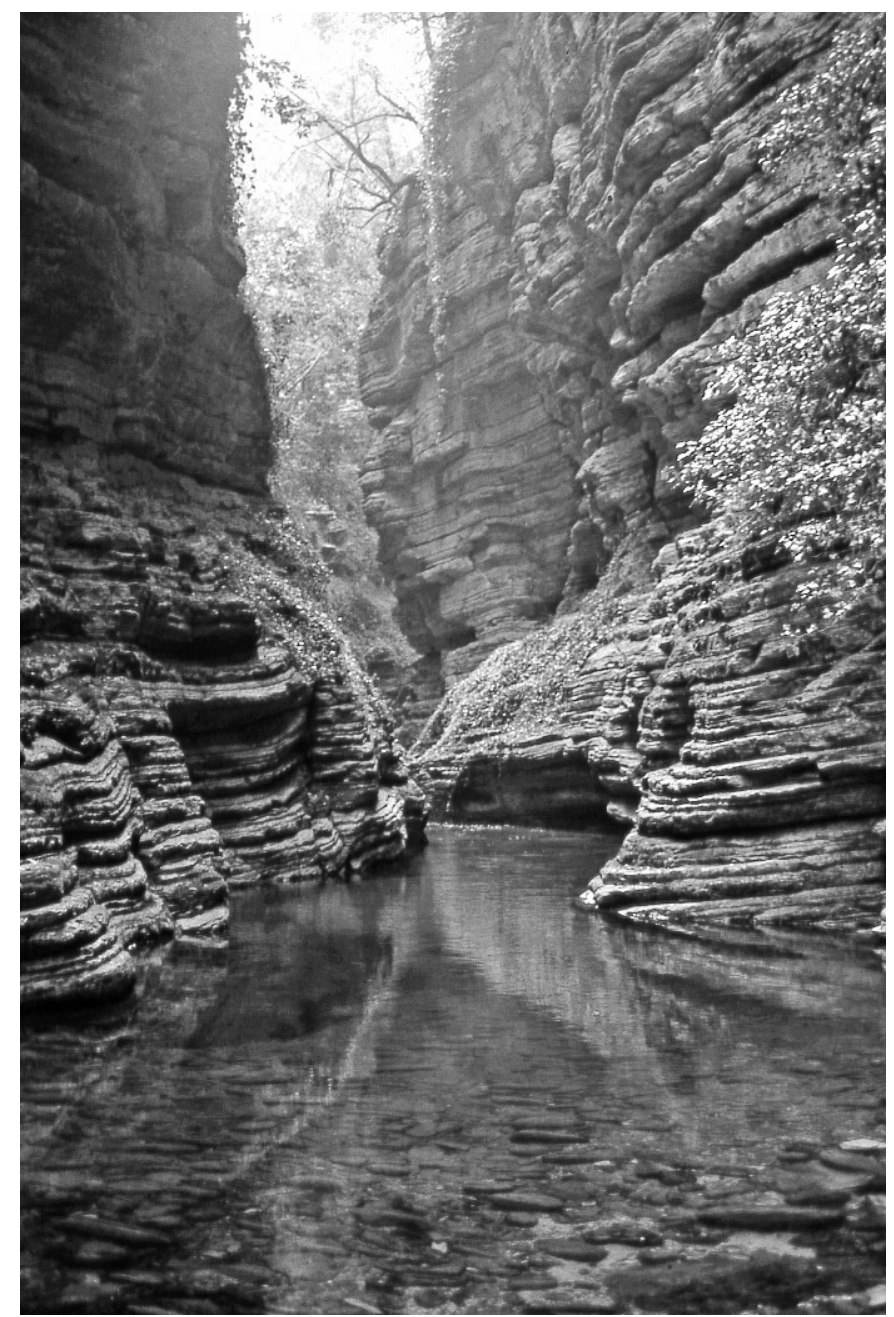

Figure 4. The Rio Garrafo gorge, at the Grotta Fredda entrance.

The main caves open at different altitudes in the vertical sides of the canyon and extend beneath the marly cover that outcrops above the canyon (Fig. 5); many passages in the caves develop below the present level of the stream. Other caves in the gorge are short fissure passages or rooms opened near the surface. These minor caves are often located in the same fracture in both the sides of the canyon. Some of these fissures near the river bed were artificially sealed in a rough attempt to prevent the loss of water in the stream (Fig. 6). Historically, the water sinking from the stream was identified as the cause of the cooling of the thermal spring.

Small travertine deposits overlying coarse fluvial gravel are on the canyon walls about $100 \mathrm{~m}$ downstream from the main cave entrances (Fig. 7). The presence of the travertine demonstrates that in the past the thermal water fed springs directly in the canyon. At present, the sulfidic water flows $\sim 50 \mathrm{~m}$ below the Rio Garrafo bed in the lower levels of the caves.

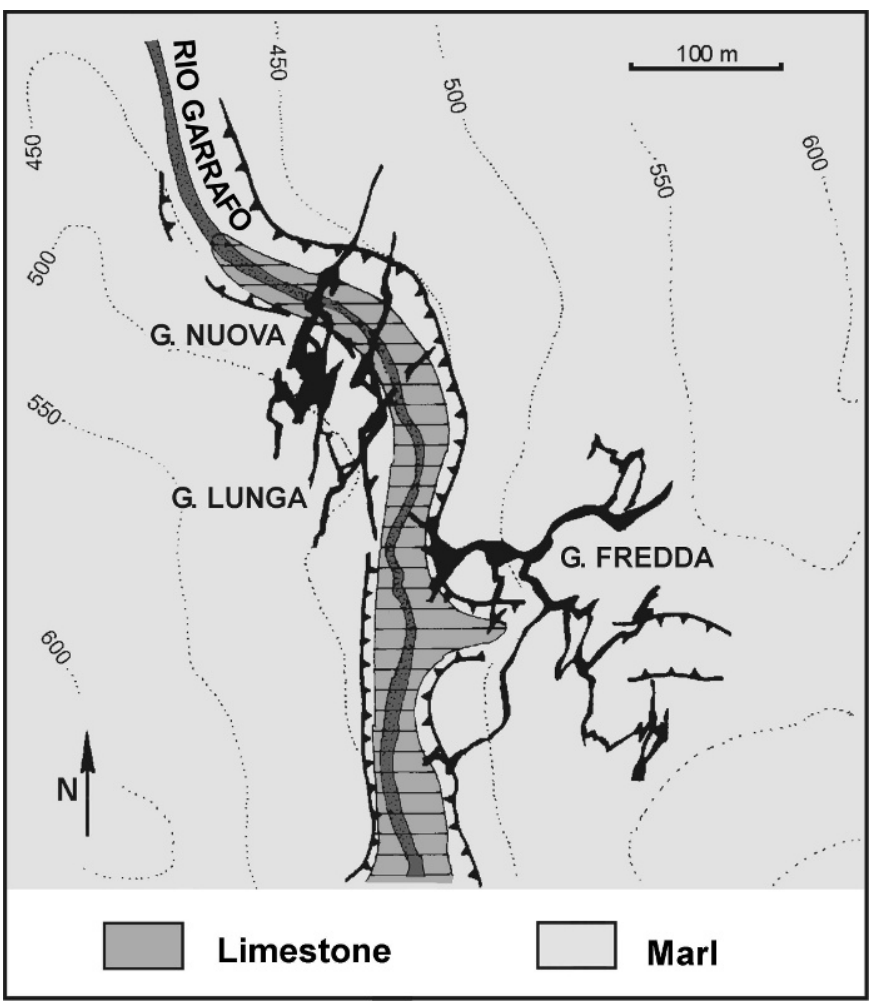

Figure 5. Plan view of the caves in the Rio Garrafo gorge. Note that caves develop below the marly cover. Cave maps based on survey by G.S.M.

\section{Grotta Fredda}

This cave has two nearby cave entrances, which open on the right side of the valley a few meters above the stream. The cave is sub-horizontal, with a ramified pattern, and consists mainly of bedding-plane passages developed at $\sim 1500 \mathrm{~m}$ (Fig. 8). The main passage has an ascending profile from the east towards the canyon and clearly following the limestone bedding. Fractures and faults

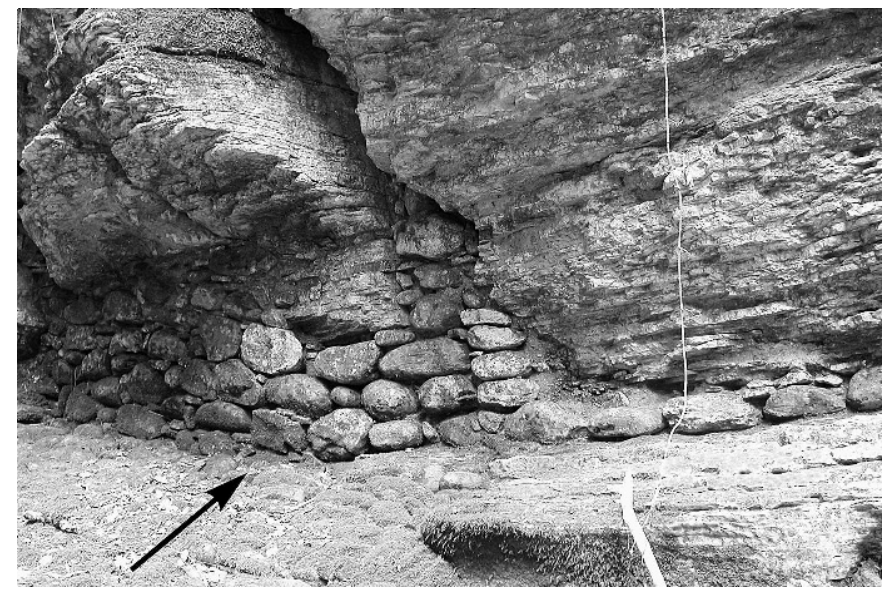

Figure 6. Old dry walls, built to waterproof the Rio Garrafo stream bed. 


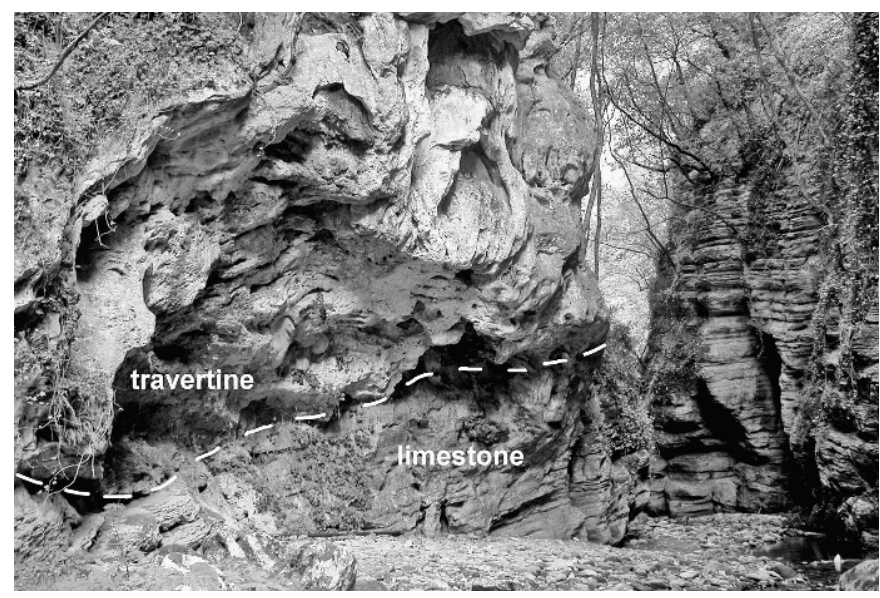

Figure 7. The small travertine deposit inside the Rio Garrafo gorge.

influence the cave development causing local changes in the direction of the main passages and in originating small lateral branches. Some fracture passages developed below the main passage and originated as crevasses that continue downward. In some crevasses, elevated rock and air temperature indicate the presence of unexplored thermal zones beneath. The low permeability of the overlying formation reduces the recharge of seepage water; therefore, flowstones develop mainly below the main fractures in the limestone.

The passage morphology is influenced by the lithology and breakdown deposits and unsteady blocks in the ceilings are common in the cave. Phreatic features prevail in the main passages with some wide cupolas on the roofs. On the floor, widespread deposits of sand partly covered by calcite deposition, might be due to past direct flooding of the cave. Furthermore, in some internal rooms, wood and shells on the walls clearly indicate the level reached by water inside the cave after recent flooding events.

White and microcrystalline gypsum occurs mainly as replacement crusts on the walls and generally it is recrystallized at the surface. The most important floor deposits can be 1-2 m thick and are clearly associated with replacement crusts and wide cupolas on the roofs (Fig. 9). These deposits often overly a silica silt that contains chert or limestone clasts. Together, the gypsum and the silt can constitute pebbly mud due to flow and redeposition.

\section{Grotta Lunga and Grotta Nuova}

These caves provide access to the groundwater in a thermal active zone $\sim 50 \mathrm{~m}$ below the Rio Garrafo bed. They were explored through two different natural entrances, but a small passage partly filled by sand was later opened by speleologists to join the caves.

These caves extend $\sim 1200 \mathrm{~m}$ and have a mainly vertical development in a fault zone with some horizontal or inclined passages at different altitudes. The upper horizon-

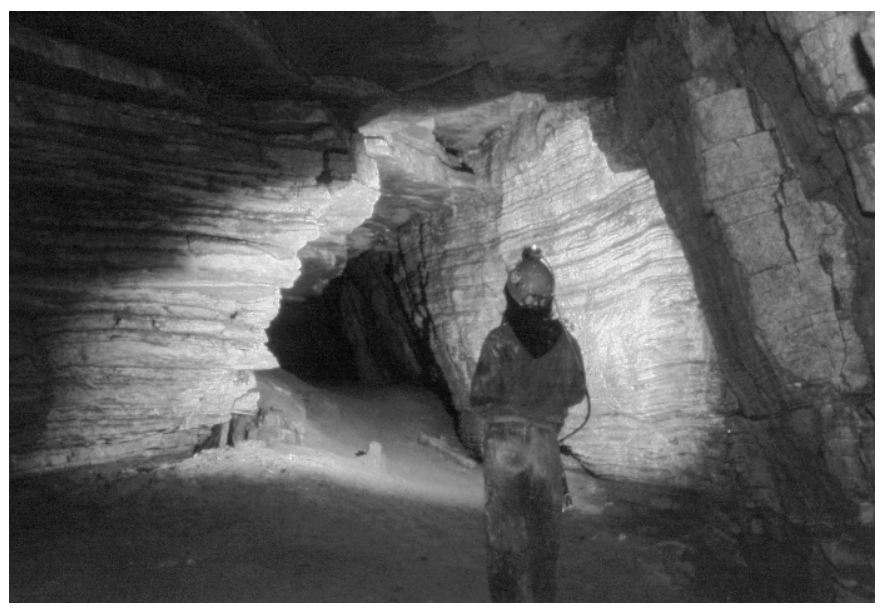

Figure 8. A typical passage in the Grotta Fredda. Sand deposits constitute the floor.

tal passages open near the entrance zones at the same altitude of Grotta Fredda. In this zone, sand deposits can be related to the past direct influence of stream water as in the Grotta Fredda. In the inclined and vertical passages, roof features show the original ascending flow of the thermal water in the phreatic zone. These passages remained in the vadose zone after the lowering of the groundwater level and a few of them are permanently utilized by sinking water directly absorbed from the Rio Garrafo stream to the thermal aquifer.

The thermal water flows in the lower part of the cave and can be reached in four different areas with different environmental conditions (Fig. 10). Upstream a pool of thermal water (named lago arsenicale, for a suspected presence of arsenic, and identified herein as anoxic lake) can be reached in the Grotta Lunga beyond a siphon, at the end of a descending passage. Here, the rise of water from the depth feeds the pool, but the low air exchange makes this place extremely dangerous because of the high temperatures and unbreathable atmosphere.

The most well-known pool (lago dei bagni, i.e., baths lake) is in the Grotta Nuova at the bottom of the main shaft. Thermal water flows in some interconnected pools and small streams coming from the anoxic lake of Grotta Lunga through flooded passages. Warm vapor clouds rise from the stream toward the shaft and the free air exchanges permits speleologists to enter the rooms for a short time.

Downstream, other pools can be reached, including a small one in a different area of the main shaft. In this pool, the descending freshwater infiltrating from the surface directly mixes with the thermal water. This mixed water, after a narrow sandy passage, joins with thermal water in the last pool (Lago della Miscela, i.e., mixture lake) where it disappears into underwater passages.

Gypsum deposits are diffuse in these caves mainly as replacement crusts on the cave walls. They can encrust the whole passage section originating as a continuous rim few cm thick. 


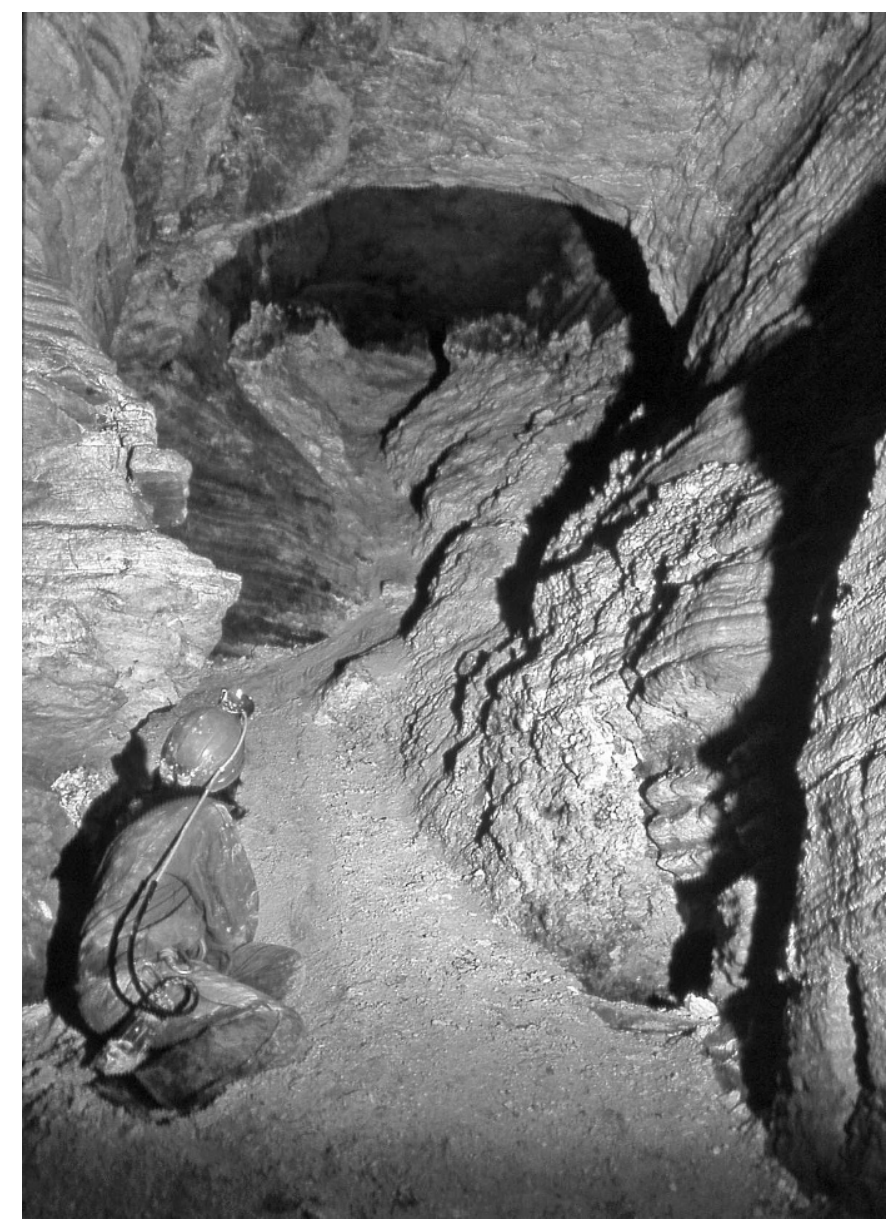

Figure 9. Cupola with gypsum deposits, in the Grotta Fredda.

Large floor deposits are rare but one is presently forming at the end of a passage in the thermal zone where active gypsum formation occurs on the cave walls. Here, the gypsum falls from the walls and is re-deposited as soft mud by the stream, occluding the passage itself. A further deposit, a few meters thick, is located on the rock bridge that divides the wide shaft over the thermal zone. This deposit, clino-stratified, originated from the detachment of replacement gypsum from the overlying wall.

\section{Labirinto Rosso}

Labirinto Rosso is a small cave ( $\sim 170$-m-long) with mainly small passages and a ramified, three-dimensional labyrinthic pattern. The cave opens near the Rio Garrafo bed in the left bank, upstream with respect to the other caves. The cave develops mainly below the present altitude of the stream and the high temperature of the limestone in some passages testifies to the presence of thermal active zones nearby. Gypsum replacement crusts also characterize many passages in this cave.

\section{The Cave Environment}

\section{Methods}

The study was based on field measurements of environmental parameters and on chemical analyses of water samples in the laboratory. Throughout the year, the water temperature was monitored every hour using four temperature loggers (Escort, New Zealand) with a resolution $\left(0.3^{\circ} \mathrm{C}\right)$ that was considered sufficient for the large range of the temperature variations. The challenging environmental conditions and possible sabotage of the instruments required thick stainless steel boxes to contain the data loggers. Preliminary measurements verified that the thermometers inside the box equilibrates with the external water temperature after $\sim 15$ minutes. After more than a year of immersion in the sulfidic groundwater, the boxes were heavily corroded, with up to 3-mm-deepcavities in the steel.

The water characteristics were analyzed at three localities: Acquasanta Terme spring, in the baths lake of Grotta Nuova (Fig. 10), and in the Rio Garrafo. Field measurements and water sampling were repeated for different hydrologic conditions and completed over a few hours. The water temperature, $\mathrm{pH}$, and conductivity were measured in situ using probes (WTW, Germany). The sulfide and the dissolved oxygen were precipitated in situ

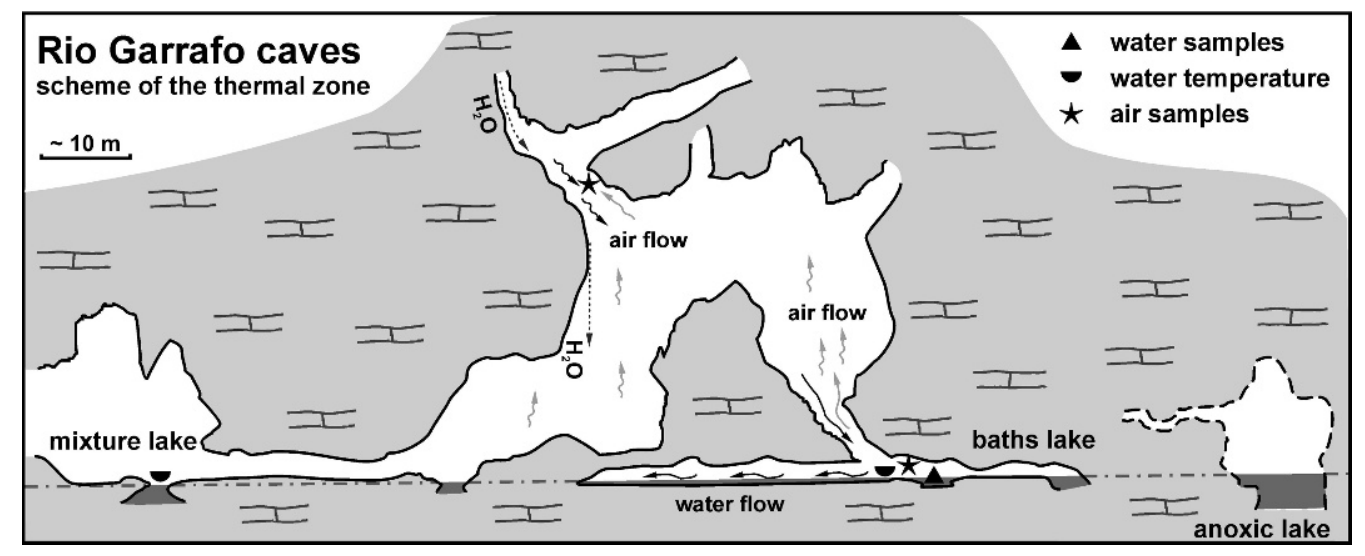

Figure 10. Map of thermal section of the cave, with sampling point locations. 
The SUlFidic Thermal CAves of AcQuasanta Terme (CENTRAl Italy)

Table 1. Chemical and physiochemical parameters of water samples and measurement methods.

\begin{tabular}{|c|c|c|c|}
\hline Parameter & Method & Range & Analytical Error \\
\hline Temperature & Digital thermometer, Hanna Instruments HI805 & -50 to $+150^{\circ} \mathrm{C}$ & $\pm 0.4^{\circ} \mathrm{C}$ \\
\hline Conductivity & Conductivity meter, Crison mod. 524 & $0.0-199.9 \mathrm{mS} \mathrm{cm}^{-1}$ & $\leq 0.5 \%$ \\
\hline $\mathrm{pH}$ & Digital pH-meter, Hanna Instruments HI 824 & $0.0-14.0$ & \pm 0.01 \\
\hline Hardness & Titrimetric Method, Standard Methods ${ }^{\mathrm{a}} 2340 \mathrm{C}$ & $0-50 \mathrm{mg} \mathrm{L}^{-1}$ & $0.8 \%$ \\
\hline Calcium & Titrimetric Method, Standard Methods ${ }^{\mathrm{a}} 3500$ B & $0-200 \mathrm{mg} \mathrm{L}^{-1}$ & $1.9 \%$ \\
\hline Magnesium & Calculation Method, Standard Methods ${ }^{\mathrm{a}} 3500$ B & $0-120 \mathrm{mg} \mathrm{L}^{-1}$ & $2.1 \%$ \\
\hline Sodium, Potassium & Flame Photometric Method, Standard Methods ${ }^{\mathrm{a}} 3500$ B & $0-50 \mathrm{mg} \mathrm{L}^{-1}$ & $0.5 \mathrm{mg} \mathrm{L}^{-1}$ \\
\hline Chloride, Sulfate & Ion Chromatography Method, Standard Methods ${ }^{\mathrm{a}} 4110$ B & $0-100 \mathrm{mg} \mathrm{L}^{-1}$ & $0.26,2.7 \mathrm{mg} \mathrm{L}^{-1}$ \\
\hline Carbon dioxide & Titrimetric method, Standard Methods ${ }^{\mathrm{a}} 4500 \mathrm{C} / \mathrm{D}$ & $10-2000 \mathrm{mg} \mathrm{L}^{-1}$ & $\pm 10 \%$ \\
\hline Bicarbonate & Titrimetric method, Standard Methods ${ }^{\mathrm{a}} 2320$ B & $10-500 \mathrm{mg} \mathrm{L}^{-1}$ & $1 \mathrm{mg} \mathrm{L}^{-1}$ \\
\hline Sulfide & Iodometric method, Standard Method ${ }^{\mathrm{a}} 4500 \mathrm{~F}$ & $0-50 \mathrm{mg} \mathrm{L}^{-1}$ & $0.1 \mathrm{mg} \mathrm{L}^{-1}$ \\
\hline Dissolved Oxygen & Iodometric method, Standard Methods ${ }^{\mathrm{a}} 4500 \mathrm{C}$ & $0-15 \mathrm{mg} \mathrm{L}^{-1}$ & $<5 \%$ \\
\hline Oxygen Saturation \% & Calculation method & $0-100 \%$ & $<5 \%$ \\
\hline Ionic balance & $\Delta \%=[($ meq. Cations - meq. Anions $) /$ meq. Cations $] \times 100$ & & \\
\hline
\end{tabular}

${ }^{\text {a }}$ Standard Methods for the Examination of Water and Wastewater $20^{\text {th }}$ Edition.

for laboratory analysis. In the laboratory, the water samples were diluted, if necessary, and their physicochemical parameters were measured using the methods shown in Table 1.

The cave air was analyzed at the same time as water sampling at two localities and at different distances from the thermal water. We used a hand pump and short-term detector tubes (Gastec Corporation, Japan) for $\mathrm{O}_{2}$ (measurement range: $3-24 \%), \mathrm{H}_{2} \mathrm{~S}(0.1-4,0.25-120$ and 1-240 ppm), $\mathrm{CO}_{2}(300-5,000 \mathrm{ppm}$ and $0.13-6 \%), \mathrm{SO}_{2}$ (0.05-10 and $0.5-60 \mathrm{ppm})$. On two different occasions, unexpectedly high $\mathrm{H}_{2} \mathrm{~S}$ and $\mathrm{CO}_{2}$ concentration exceeded the ranges of the available tubes.

\section{WATER Chemistry}

Groundwater comprises two main types, bicarbonate and sulfidic. Bicarbonate water in the vadose zone consists of dripping water derived from the infiltration of meteoric water through fissures in the low permeable marly limestone, or which sinks directly through the bed of the Rio Garrafo stream.

The Rio Garrafo water, that in part feeds the thermal aquifer, was analyzed together with sulfidic water (Table 2). The stream water has a low salinity (about 250 $300 \mathrm{mg} \mathrm{L}^{-1}$ ) and a prevailing bicarbonate composition. The temperature fluctuates with seasonal cycles, while the chemical characteristics have shown only minor changes during the period. Once inside the cave, the stream water flows in wide inclined channels and quickly joins the thermal water in the deep zones of the cave.

The sulfidic thermal water has a higher salinity than the bicarbonate water, up to $7 \mathrm{~g} \mathrm{~L}^{-1}$, has a high content of chloride, sodium, calcium, bicarbonate, sulfate, and contains hydrogen sulfide. These dissolved components are acquired before the water rises upward. The thermal water was sampled in the small stream at the entrance of the baths lake zone of Grotta Nuova before the junction with a descending stream of infiltrating freshwater (Fig. 10) and at the outflow of the Acquasanta Cave, the main sulfidic spring for the whole area. Water levels in the Grotta Nuova can increase up to $2.5 \mathrm{~m}$ during flooding events even though changes in the water levels were not observed on the sampling dates described here. From Grotta Nuova, the spring is almost $2 \mathrm{~km}$ distant and $\sim 20 \mathrm{~m}$ deep; therefore, the hydraulic gradient should be $\sim 1 \%$.

The sulfidic water in the Acquasanta spring is more diluted than in the Grotta Nuova, but the seasonal trend of conductivity, salinity, and temperature is very similar (Fig. 11). The lowest values for these parameters occurred in April when rains and snow melt cause an increase in the surface discharge. In the Grotta Nuova, salinity ranged between $7.2 \mathrm{~g} \mathrm{~L}^{-1}$ (October 16, 2004, water temperature: $42.2^{\circ} \mathrm{C}$ ) and $4.4 \mathrm{~g} \mathrm{~L}^{-1}$ (April 26, 2004, water temperature: $33.1^{\circ} \mathrm{C}$ ). In the Acquasanta spring, salinity values were lower with the same seasonal variations; the highest values were on December 1, 2003 (4.6 $\mathrm{g} \mathrm{L}^{-1}$; temperature $31.4^{\circ} \mathrm{C}$ ), and the lowest occurred on April 26, 2004 $\left(1.9 \mathrm{~g} \mathrm{~L}^{-1}\right.$; temperature $\left.21.9^{\circ} \mathrm{C}\right)$. Cation and anion compositions confirm the differences between these two types of water (Table 2). The concentration of ions is higher in the Grotta Nuova and follows the same annual trend, even if the seasonal dilution is less important than in the Acquasanta spring. In the baths lake of Grotta Nuova, the $\mathrm{pH}$ values are lower than in Acquasanta spring where the deposition of small amounts of carbonate occurs. During flood events, the $\mathrm{pH}$ values decreases at both locations.

To estimate the importance of the seasonal dilution, we assumed that the dilution is mainly due to the mixture of bicarbonate water that has low chloride content $\left(\sim 0.3 \mathrm{mmol} \mathrm{L}^{-1}\right)$ with the rising thermal water. Therefore, we compared chloride concentration in each sample with 
S. Galdenzi, F. Cocchioni, G. Filipponi, L. Morichetti, S. Scuri, R. Selvaggio, and M. Cocchioni

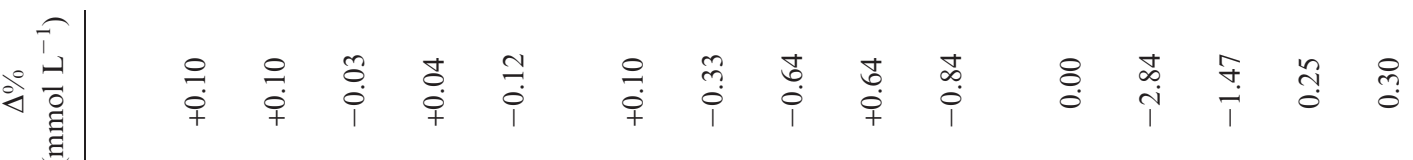

离

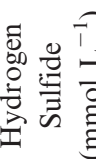

$\stackrel{\overbrace{}}{1}$

궁

苞言

点

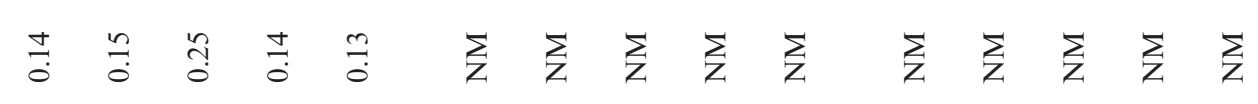

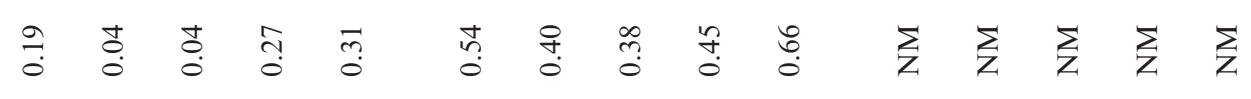

这

望

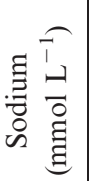

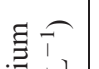

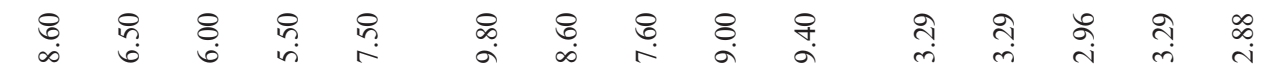

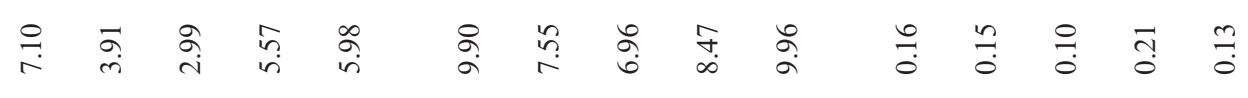

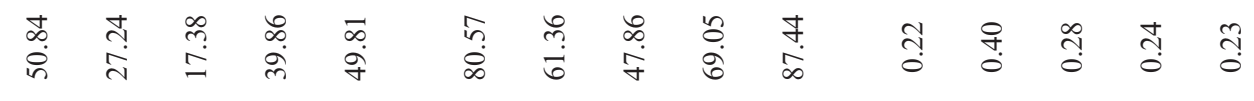
咅

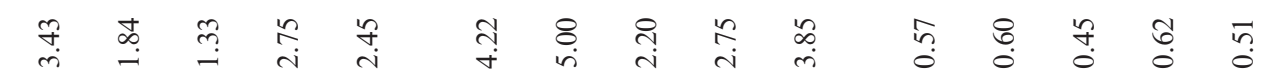

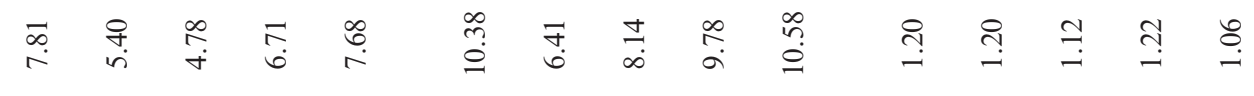

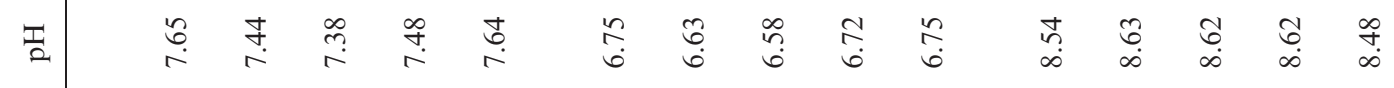

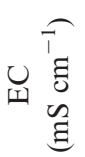

竞

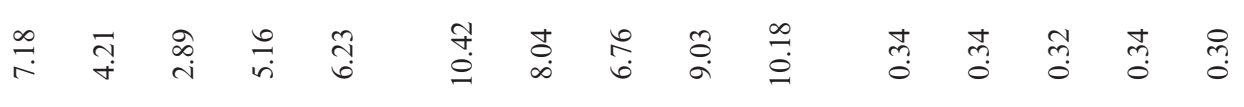

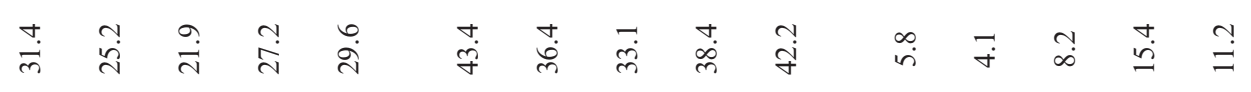

苞

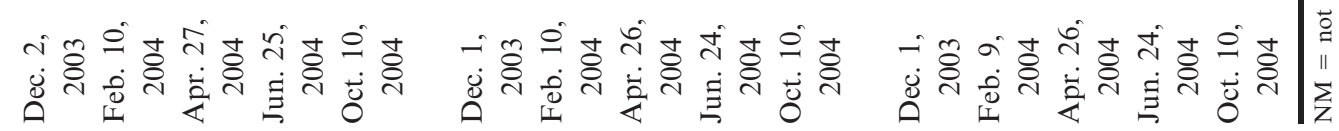




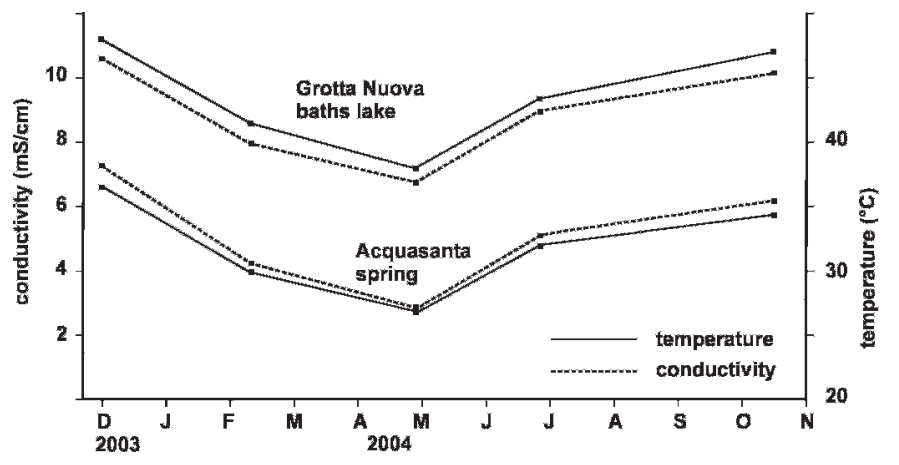

Figure 11. Correlation between temperature and conductivity in the Acquasanta spring and in the baths lake of Grotta Nuova on the sampling dates.

the values measured in the Grotta Nuova in October after a long dry period. Simple analytic calculations show that in the same lake the October water was diluted with $\sim 45 \%$ of freshwater during flood events. In the Acquasanta spring, the dilution calculation for the Grotta Nuova water varied between $\sim 40 \%$ in the autumn and $80 \%$ during floods. Seasonal changes in sodium and potassium content have the same seasonal trend as chloride, while the other major ions have a slightly different seasonal trend influenced by interaction with the bedrock and oxidation-reduction reactions.

Dissolved $\mathrm{H}_{2} \mathrm{~S}$ has higher concentration values in the Grotta Nuova (up to $0.66 \mathrm{mmol} \mathrm{L}^{-1}$ ) when compared to Acquasanta spring where values were as high as $0.31 \mathrm{mmol} \mathrm{L}^{-1}$. The sulfide, however, represents a small percentage (not exceeding 6\%) of the total sulfur species dissolved in the water. The concentration of dissolved $\mathrm{H}_{2} \mathrm{~S}$ follows the general dilution of the thermal groundwater in the baths lake of Grotta Nuova, while during floods in the Acquasanta spring, it decreases to $0.04 \mathrm{mmol} \mathrm{L}^{-1}$. These low values cannot be due only to dilution by nonsulfidic water, but are also accompanied by an increase in the dissolved $\mathrm{O}_{2}$ concentration, suggesting that oxidation due to oxygenated freshwater from the surface contributes to $\mathrm{H}_{2} \mathrm{~S}$ decrease in the water.

\section{WATER TEMPerature}

The temperature of the water was monitored with data loggers placed at the same points where water samples were collected (i.e., Rio Garrafo Gorge, baths lake of Grotta Nuova and Acquasanta Spring, the outflow of Acquasanta Cave) and in the mixture lake of Grotta Nuova, where a stream of vadose water infiltrated from the Rio Garrafo directly mixes with the thermal sulfidic groundwater.

The thermograms confirm the seasonal variations suggested by the water chemistry and indicate that the water temperature was influenced by rain and flood events (Fig. 12). After a flood event, the temperature dropped quickly and the return to the pre-existing temperatures required a longer time. The maximum water temperature

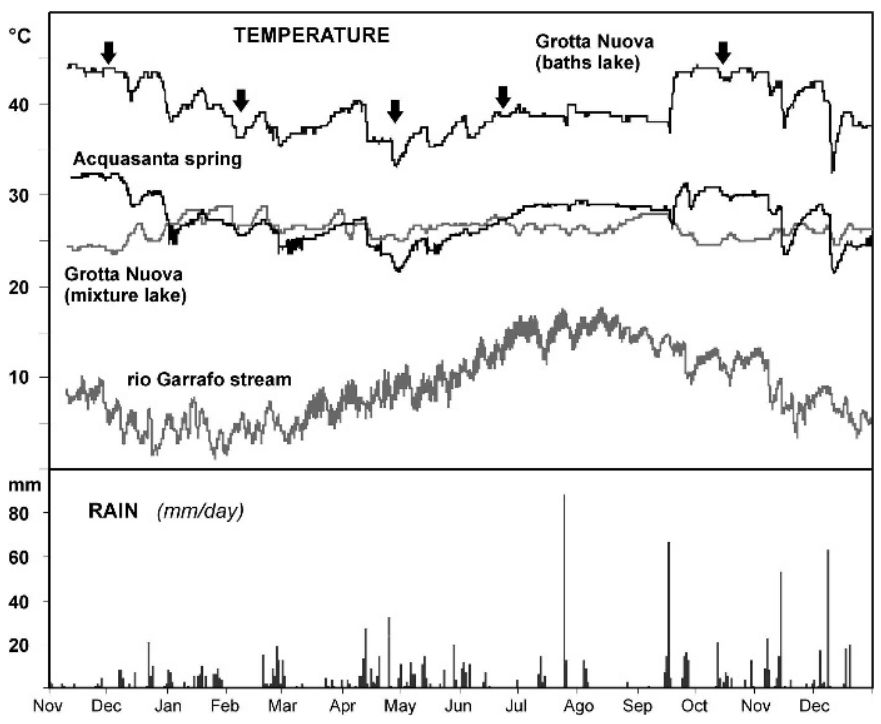

Figure 12. Temperature in the groundwater related to rain during the monitoring period. The arrows indicate the sampling days.

was $\sim 44^{\circ} \mathrm{C}$ in baths lake of Grotta Nuova and $\sim 32^{\circ} \mathrm{C}$ in the Acquasanta spring. Therefore, water samples collected December 1, and October 16, 2004, are representative of low-dilution periods. The lowest temperature values occurred on April 26, 2004 and December 10 and 11, 2003 (baths lake of Grotta Nuova, $\sim 33^{\circ} \mathrm{C}$; Acquasanta spring, $\sim 21^{\circ} \mathrm{C}$ ). The April 26 samples represent the composition of water during one of the main floods in the cave, corresponding to the most diluted water that occurred over the whole year. In the mixture lake of Grotta Nuova, the water temperature remained lower than in the baths lake throughout the year.

The thermograms of Grotta Nuova baths lake and Acquasanta spring have the same trends and changes in temperature are clearly related in timing and duration (Fig. 12). The temperature decrease in Grotta Nuova is very rapid following flooding events in the Rio Garrafo. The same occurs in the Acquasanta spring, showing that the spring is directly influenced by the same flooding events, but here the lowest temperature values are reached later, by a few days, and maintained for a longer time compared to baths lake (Fig. 13).

Thermograms for the two lakes of Grotta Nuova during the flooding events may have different trends. In most periods, flood events cause temperature decreases in both lakes (Fig. 13A, B). Sometimes, however, the two lakes show opposite variations during the same flood (Fig. 13C). While the baths lake is directly influenced by surface meteoric events, the mixture lake floods may produce a temperature increase. This is due to changes in the discharge of the karst channels that feed the lake with vadose and thermal water, which can cause a more direct contact between the warm water and the thermometer, with a consequent increase in the measured temperature. 

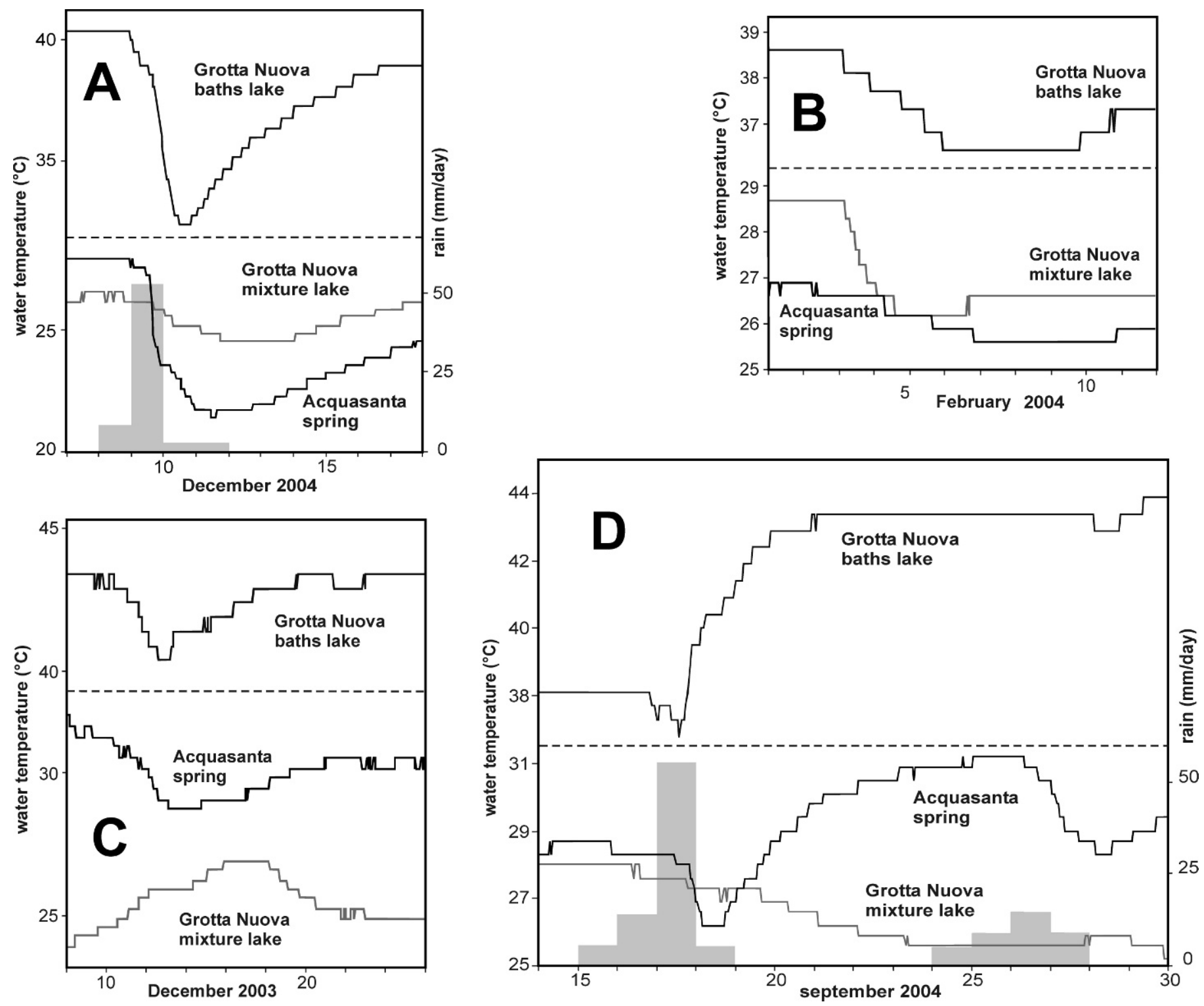

Figure 13. Temperature changes during flooding events. (A) The groundwater temperature after the rain of December 9, 2004. (B) February, 2004 - the arrival of freshwater was due to snow melt in the surrounding mountains. (C) December 11, 2003, temperature changes after an isolated snowfall in the mountains. (D) Groundwater temperature at the end of summer, after the rain of September 17, 2004.

Changes in water temperature during the summer are further indications of the complex pattern of karst water flow. In dry periods, corresponding to the lowest recharge of cold freshwater, the increase of water temperature ceased at all the monitoring locations. In the baths lake, the temperature remained even lower than the average annual temperature, probably due to slow water flow and heat exchange with the rock. A major rain event at the end of the summer (September 17) caused a small, but rapid decrease in water temperature in the baths lake and in the Acquasanta spring (Fig. 13D). In the following days, water temperature increased in the baths lake $\left(\Delta T \sim+6^{\circ} \mathrm{C}\right)$ and in the spring $\left(\Delta T \sim+3^{\circ} \mathrm{C}\right)$, while temperature decreased in the mixture lake $\left(\Delta T \sim-2^{\circ} \mathrm{C}\right)$. Similar changes, with a lesser range, also occurred after an important isolated rain event, on July 25 (Fig. 12). These data suggest that after these rains, the infiltration of surface water produced an increase in hydraulic pressure and a faster water flow, which restored normal conditions at the end of the dry season with an increase in water temperature at the spring and at the baths lake.

The thermograms and water chemistry of Grotta Nuova and Acquasanta spring suggest a different importance at the input of freshwater in the different sites. The mixture lake water has a generally lower temperature due to the direct arrival of freshwater and is also affected by 


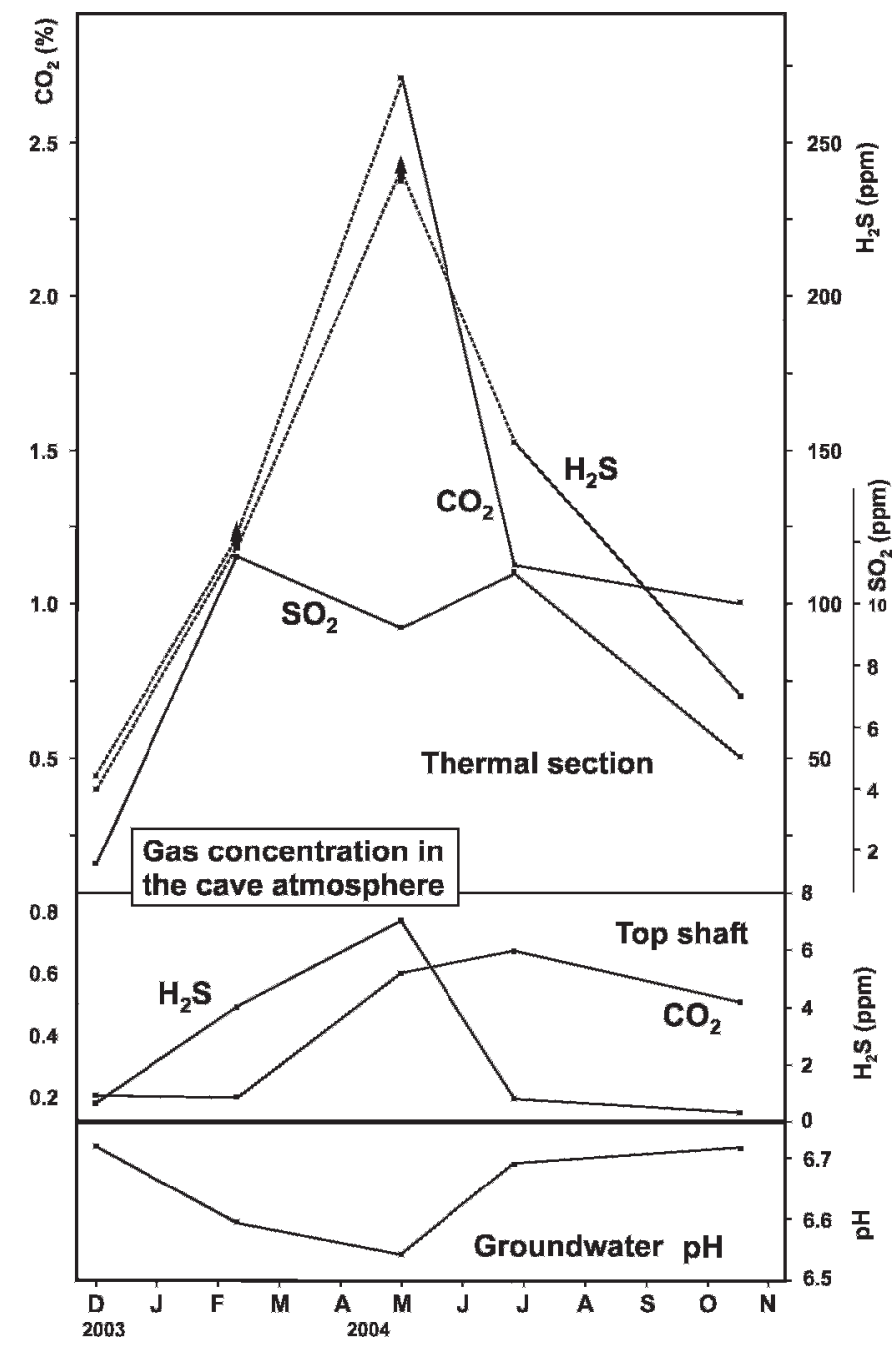

Figure 14. Relationships between gas concentration in the cave atmosphere and $\mathrm{pH}$ in the groundwater. The arrows indicate values outside the range of the available detector tubes. Therefore the reported values are minimum estimates.

changes resulting from flow of thermal and vadose water. The baths lake is directly influenced by the flood events that cause dilution immediately after the meteoric events. Acquasanta spring is also directly influenced by a rapid recharge of freshwater through karst passages, but it is probable that the average temperature and salinity remain lower than in the Grotta Nuova partly because of the contribution of water infiltrating from Rio Garrafo. Thermal water dilution at the spring might also depend on the contribution of different sources of water infiltration in the Tronto Valley, including the large travertine plate where the Acquasanta Cave and spring develop.

\section{Air Composition}

The air composition changes in the different cave branches, depending on the connection with the sulfidic lakes or streams and with the surface. Extremely dangerous conditions for humans are present in isolated rooms, such as the anoxic lake in the Grotta Lunga where the small water-filled entrance reduces air exchange with the nonsulfidic upper cave levels.

After considering the features of the rooms and the difficulties of accessing them with appropriate safety equipment, we decided to analyze the air composition in the main room of Grotta Nuova where water samples were also collected. This room has a complex structure (Fig. 10). It is developed along a fault and is divided by a rock bridge into two different shafts. Sub-horizontal or inclined passages intersect the room in its upper and lower parts and active flow of sulfidic thermal water occurs in the lowest zones. Two room entrances are known, constituted by an inclined passage and by a narrow shaft, that isolate the room from the upper zones of the cave. A small waterfall of freshwater, infiltrated from the Rio Garrafo stream, permanently runs along the shaft wall coming from a narrow vertical passage.

The cave atmosphere is influenced by the gas released from the thermal water. The presence of sulfur gases is clearly detectable by smell at the top of the room near the entrances. A first sampling point was located at the top of the shaft, where the rising sulfur-rich air mixes with air coming from the surface (Fig. 10). The second sampling point was at the bottom of the shaft, inside the warm zone of the baths lake at the same location where water samples were collected. The high temperature, humidity, and dangerous air composition, allow only a few minutes for sample collection. This thermal part of the cave is welldivided from the remaining part of the room by a small descending passage where a steam cloud continuously rises and mixes with the cave air.

The air composition at both sampling sites was significantly influenced by gases released from the sulfidic water (Fig. 14). The $\mathrm{O}_{2}$ concentration remained high $(\sim 20 \%)$, thanks to rapid air exchange with the nonsulfidic sections of the cave. The amount of $\mathrm{CO}_{2}, \mathrm{SO}_{2}$, and $\mathrm{H}_{2} \mathrm{~S}$ was significantly higher in the thermal section than at the top of the shaft. In the thermal zone, the $\mathrm{CO}_{2}$ varied between $0.44 \%$ to $2.7 \%, \mathrm{H}_{2} \mathrm{~S}$ between 40 to over $240 \mathrm{ppm}^{1}$, and $\mathrm{SO}_{2}$ between 1.1 to $9.2 \mathrm{ppm}$. At the top of the shaft, the $\mathrm{CO}_{2}$ ranged between $0.20 \%$ and $0.64 \%, \mathrm{H}_{2} \mathrm{~S}$ between 3 and $8 \mathrm{ppm}$, while $\mathrm{SO}_{2}$ had lower concentrations, not exceeding $0.2 \mathrm{ppm}$.

The most extreme conditions were measured on April 26, after a strong rain event when $\mathrm{CO}_{2}, \mathrm{SO}_{2}$, and $\mathrm{H}_{2} \mathrm{~S}$ reached maximum percentages in the air. This unexpected high concentration of gases in the air made measurement

\footnotetext{
${ }^{1}$ Editors Note: The atmospheric concentrations of $\mathrm{H}_{2} \mathrm{~S}$ reported here are hazardous to human health. The United States Occupational Safety and Health Adminstration (OSHA) has specified a Permissible Exposure Limit (PEL) of $10 \mathrm{ppm}$ and an Immediately Dangerous to Life and Health (IDLH) limit of $100 \mathrm{ppm}$. Atmospheres with $\mathrm{H}_{2} \mathrm{~S}$ at the concentrations reported here should not be entered without proper monitoring and protective equipment.
} 
and sampling operations very difficult. Similar flooding incidents have also put cavers in danger in the past.

Seasonal variations in the cave atmosphere composition have similar trends at both sampling locations (Fig. 14). Minor differences may be attributable to differences in the air flow patterns in the cave during the cold and warm seasons. Gas concentration is clearly related to the hydrologic cycle and increases for the dilution of thermal water by the freshwater. The highest values occurred during important flooding events, confirming cavers' observations about unbreathable air in the days following large rain events.

The gas concentrations have an opposite trend to water temperature, conductivity, and dissolved gases or their ionic equivalents. $\mathrm{H}_{2} \mathrm{~S}$ in the air has higher values when total sulfide concentration in the water is lower. A similar trend also occurs for $\mathrm{CO}_{2}$ in the air and $\mathrm{HCO}_{3}^{-}$in the water. The increase in gas released to the cave atmosphere is correlated with $\mathrm{pH}$ (Fig. 14). At values close to the $\mathrm{pK}$ of $\mathrm{H}_{2} \mathrm{~S}$ and $\mathrm{H}_{2} \mathrm{CO}_{3}, \mathrm{pH}$ influences the following equilibria:

$$
\begin{gathered}
\mathrm{H}^{+}+\mathrm{HS}^{-} \leftrightarrow \mathrm{H}_{2} \mathrm{~S} \\
\mathrm{H}^{+}+\mathrm{HCO}_{3}^{-} \leftrightarrow \mathrm{H}_{2} \mathrm{CO}_{3} \\
\mathrm{H}_{2} \mathrm{CO}_{3} \leftrightarrow \mathrm{H}_{2} \mathrm{O}+\mathrm{CO}_{2}
\end{gathered}
$$

For this reason, the lowering of $\mathrm{pH}$ favors the release of $\mathrm{H}_{2} \mathrm{~S}$ and $\mathrm{CO}_{2}$ into the cave atmosphere.

\section{Discussion}

The development of the Acquasanta caves is related to the rise of thermal water at the core of the anticline and the oxidation of $\mathrm{H}_{2} \mathrm{~S}$ enhanced by the recharge of freshwater is probably the main cave forming process (Galdenzi, 1997). The characteristics of each cave are influenced by the hydrologic and geomorphologic settings and by their evolution through time.

The Acquasanta Cave is a young cave, formed after the deposition of the lowest travertine plate in the Tronto Valley. The explored part of the cave represents the outflow of sulfidic water rising from the thermal aquifer and flowing at the bottom of the travertine plate, influenced by the difference of permeability with the underlying marl. The cave has evolved near the water table, and easy gas changes with the atmosphere produce condensation corrosion on the walls in the whole cave.

The Rio Garrafo caves have had a more complex history. Their general features are due to their development as phreatic passages, but each zone of the cave has been influenced by different processes after the water table lowered to its present level. Their evolution will be discussed in detail in the following sections, considering both active processes and old morphologies and deposits. They also provide a useful example of the evolution of speleogenetic conditions in hypogenic caves as a consequence of the increase of direct connections with the surface.

\section{Active Processes}

Large parts of the old phreatic passages in the Rio Garrafo caves emptied after the lowering of the groundwater level, and thermal water flow continued down into the lowest sections of the caves where sulfidic water is in contact with the cave atmosphere in a few rooms. The analytic measures demonstrate that the thermal water chemistry undergoes seasonal changes because of the variable recharge of cold meteoric water. This recharge of $\mathrm{O}_{2}$-rich water can contribute to maintain active solutional processes in the thermal groundwater because it can cause the oxidation of $\mathrm{H}_{2} \mathrm{~S}$ to sulphuric acid and the consequent dissolution of limestone where the mixture of waters occurs.

Above the water table, the cave evolution is mainly due to dripping water, sinking stream water, and gases released from the thermal zones, which have a different importance in each part of the caves.

The flow of dripping water has produced flowstone in some parts of the cave, but this process is significant only in some rooms and passages. The thick marly cover, in fact, prevents infiltration, which is possible only through important fractures or faults, or in the zones nearest to the gorge where the limestone outcrops. Also, the water directly infiltrated from Rio Garrafo does not play a significant morphogenetic role and causes only minor changes in the old phreatic passages utilized by water to descend.

In the zones directly exposed to the flow of thermal water, the release of gas has important influences on the cave evolution. The high bicarbonate content of thermal water causes the release of $\mathrm{CO}_{2}$ when the water reaches the cave atmosphere; this phenomenon, however, produces deposition of carbonates only at the outflow of the Acquasanta Cave, where gours are forming in the stream before it reaches the surface.

Inside the caves, corrosion due to condensing water is the dominant process. Steep air temperature gradients favor air convection, and gases released from the groundwater consequently rise toward the upper levels. Low $\mathrm{pH}$ values were measured in all the rooms sampled for gas composition, including at the top of the shaft (Fig. 10). These data are consistent with the presence of $\mathrm{H}_{2} \mathrm{~S}$ and $\mathrm{SO}_{2}$ detected in the air. The oxidation of $\mathrm{H}_{2} \mathrm{~S}$ leads to an active replacement of the limestone with gypsum in all zones, even where the walls are not directly exposed to the thermal water flow. The gypsum can be white or weakly colored due to impurities in the marly limestone and is generally found as thin crusts that are re-crystallized at the surface. The intensity of the corrosion strongly increases in the thermal section where the walls are more directly exposed to the degassing phenomena. A continuous crust of gypsum covers the walls and ceilings; the crust can be 

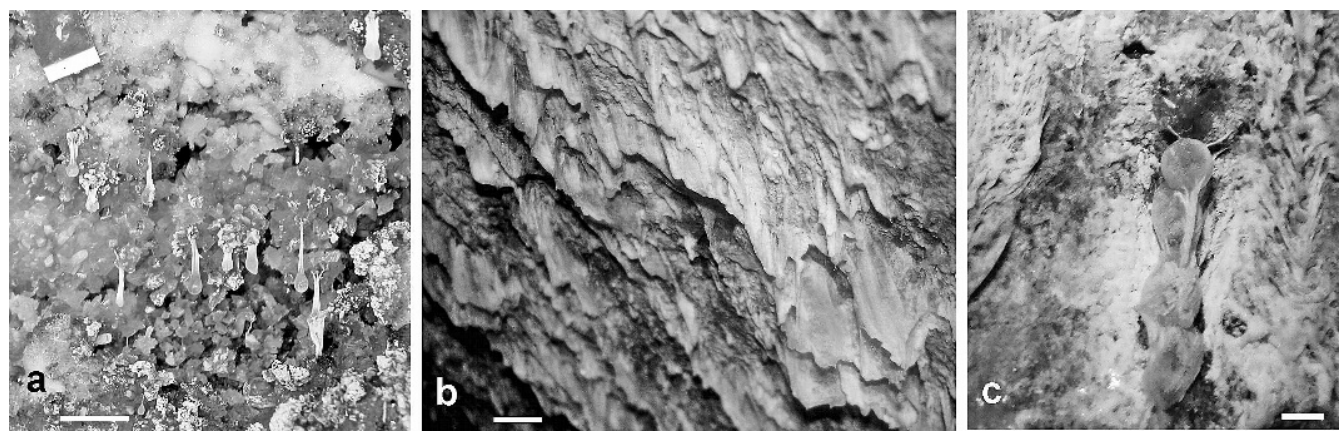

Figure 15. Organic formations at the entrance of the thermal zone (Scale bar: $\sim 1 \mathrm{~cm}$ ). (a) stalactites with acidic droplets; (b) curtains; (c) sequence of gas-filled and empty balloons.

dry, and often it is detaching from the limestone. In the places most directly exposed to degassing, elemental sulphur deposits are found on the walls and the gypsum.

Gypsum replacement crusts, however, are also in zones of the cave that, at present, are not influenced by the flow of thermal water. These deposits testify to the past influence of gas released by thermal water in a different hydrologic or morphologic setting.

\section{Gypsum Formation and Biologic Aspects}

Actively forming gypsum crust at Acquasanta has different features when compared with gypsum crusts observed in Frasassi sulfidic zones. At Frasassi, the gypsum is a moonmilk-like rim growing in a well-defined surface crust or in limestone pockets. In contrast, in the Acquasanta caves, the replacement gypsum has a gradational relationship to the underlying limestone. This is probably due to the higher silt and clay content of the limestone, which favors alteration without a well-defined separation surface. To clarify this aspect, limestone tablets composed of Acquasanta marly limestone were exposed for three years in the Frasassi caves, repeating an experiment previously conducted using pure limestone tablets (Galdenzi et al., 1997). The pure limestone tablets in the first experiment were covered by a thin layer of gypsum, whose removal revealed a hard, irregularly corroded limestone surface with incipient pockets a few millimeters deep. In contrast, the marly limestone tablets were covered by a layer of gypsum grading through a nondefinite surface into a soft, friable layer of limestone which crumbled as the gypsum was removed. Compared to other caves known to have active gypsum formations, such as Frasassi (Sarbu et al., 2000) and Cueva de Villa Luz (Hose et al., 2000), the growth of gypsum replacement crusts at Acquasanta is rarely associated with evident biofilms.

Inside the thermal zone, bacterial mats colonize the running sulfidic water, but no macroscopic evidence of life was found on the walls above the water table. On the contrary, thin, extremely acidic ( $\mathrm{pH} 0-1)$ organic formations are present at the entrance to the thermal zone where curtains, stalactites, and balloons (Fig. 15) are forming in a zone with active condensation phenomena, due to the rapid rise of warm air. These thin, weak structures, swinging in the air currents, disappear in the intensely thermal zone below and are also absent on nearby walls not directly influenced by the warm air currents and condensation. Their development is likely related to sulfur oxidizing bacteria or archaea (Jones et al., 2006). Sulfur bacteria living at extremely low $\mathrm{pH}$ have been described at Frasassi and Cueva de Villa Luz (Vlasceanu et al., 2000; Hose et al., 2000; Macalady et al., 2007).

In the same room, in the zones not directly exposed to intense warm air flow, small zones of the walls with active gypsum growth are covered by a thin organic layer that can give rise to small gelatinous stalactites. These formations are similar to widespread features described in the Frasassi caves (Vlasceanu et al., 2000; Macalady et al., 2007), where the active gypsum replacement crust is often covered by an organic layer involved in the oxido-reduction of sulphur species.

In the Frasassi caves, bacterially-produced organic matter on the cave walls represents the main food source for the cave fauna (Sarbu et al., 2000), as shown earlier in Movile Cave (Sarbu and Kane, 1995; Sarbu et al, 1996). Preliminary research carried out in Acquasanta in 1997 revealed a non specialized fauna, with surface sources of organic matter (bat guano) as the main food source (Sarbu, unpublished data). At present, however, the importance of life, its adaptation to the cave environment, and the possible role in speleogenesis are interesting subjects that remain to be explored and discussed.

\section{Origin and Evolution of the Caves}

The general development of the Rio Garrafo caves can be related to the same speleogenetic processes that are still active, although changes in the geomorphic and hydrogeologic setting in the area through time also have influenced speleogenesis and cave characteristics. The cave development began under phreatic conditions because of the rise of thermal water to the surface through vertical fissures in the marl units. These first phases that were partly concealed by the subsequent evolution probably 
occurred before the stream valley had cut down to the top of the limestone sequence.

The progressive deepening of the valley, however, permitted the stream to reach the top of the limestone sequence, where erosion of the gorge began. The pre-existing small passages remained perched above the water table, where they had evolved only because of the flow of vadose water. The thermal water flow continued into the upper part of the limestone sequence. In this phase, the mainly horizontal passages of Grotta Fredda and the upper levels of Grotta Nuova and Grotta dei Pipistrelli evolved, at the same altitude as the small travertine deposits produced by thermal springs in the Rio Garrafo gorge (Fig. 16A). Because the stream bed was close to the water table, small changes in the stream bed elevation could have emptied the cave passages or caused a return to phreatic conditions, also favoring the deposition of sand in the caves.

An important change in the evolution of these upper cave levels was due to the deepening of the Tronto Valley, which also caused the deepening of the tributary valleys and the generalized lowering of the regional base level. The most important consequence of this event was the lowering of the water table in the Rio Garrafo Valley where it became significantly lower than the canyon bottom (Fig. 16B). Therefore, after this event, direct input of thermal water at the surface in the canyon was no longer possible and the cave water emerged at the main spring farther downstream in the Tronto Valley. Moreover, the stream remained perched above the already karstified limestone and rapid recharge of surface water to the aquifer through the pre-existing phreatic karst passages became very easy. The deepening of the canyon bottom also prevented any direct flooding of stream water in the upper level of Grotta Fredda and Grotta Lunga where dripstones covered the old sand deposits.

These old cave levels, however, were newly influenced by the stream because the recent deposition of gravel in this part of the gorge caused a small increase in the elevation of the stream bed. Subsequently, stream water could flood the Grotta Fredda in rare occasions as evidenced by the recent wall deposits of organic material floated into the cave.

The changes in the geomorphic and hydrologic setting significantly modified the speleogenetic conditions for the cave development over time. In the beginning, the surface recharge of freshwater was probably low and the cave evolved mainly under phreatic conditions even if the progressive deepening of the Rio Garrafo Valley facilitated exchanges between thermal and surface stream water in the caves (Fig. 16A). After the deepening of the main surface stream (Tronto River) and resulting lowering of the water table, the amount of water infiltrating from the Rio Garrafo strongly increased, while interfaces between the cave atmosphere and the thermal water became more common inside the pre-existing cave passages (Fig. 16B). Rapid air exchange with the surface also favored condensation corrosion and gypsum formation on the cave walls.
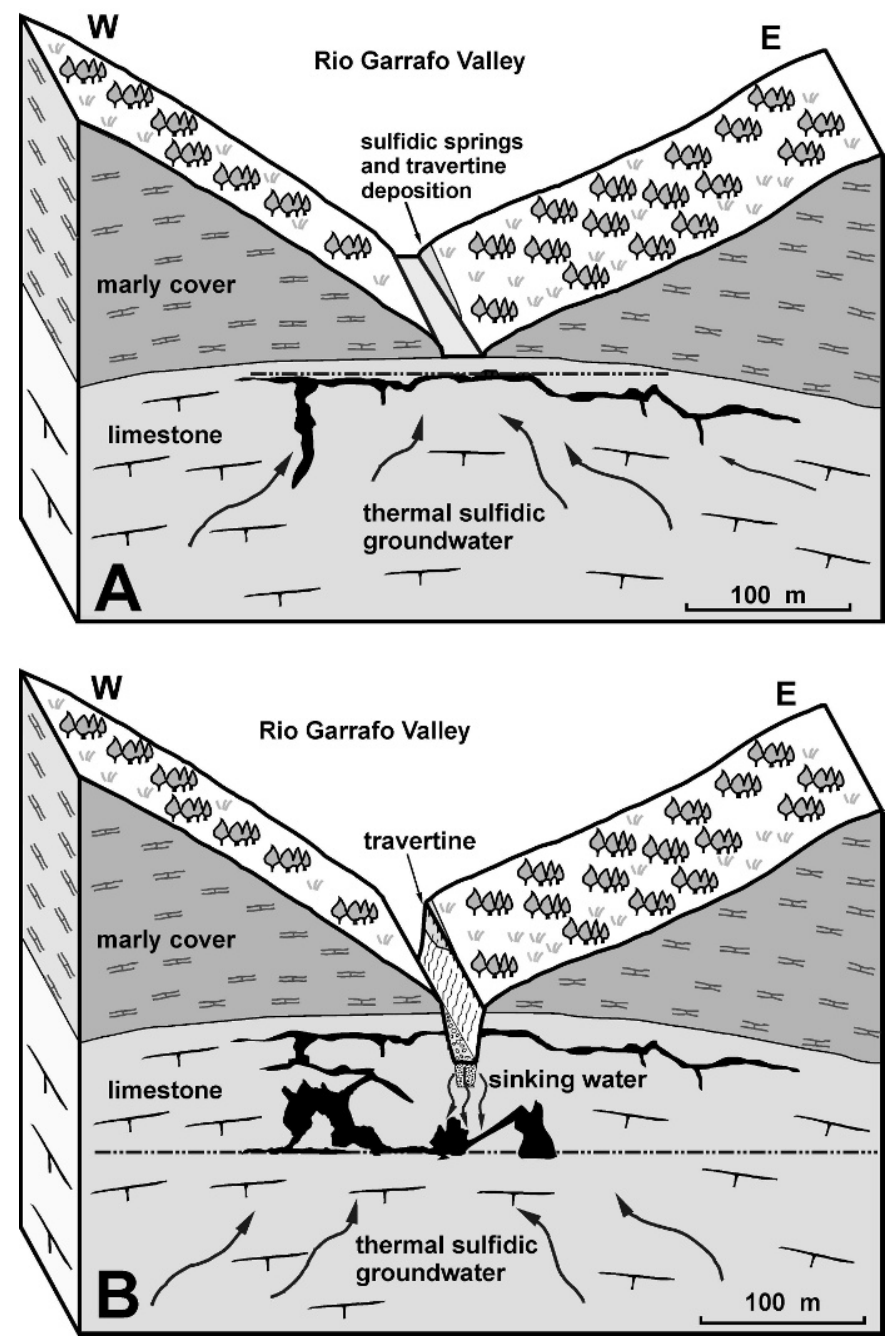

Figure 16. Sketch of the Rio Garrafo karst area. (A) The gorge in the past, with sulfidic spring located in the valley. (B) The gorge in the present, after the lowering of the water table. The water loss from the stream can easily reach the thermal groundwater.

\section{Conclusions}

The Acquasanta hypogenic caves formed at the core of an anticline because of the rise of thermal water in a capped aquifer hosted in the carbonate sequence. Cave development, however, was influenced by changes in the surface geomorphic and hydrologic setting, which have modified the morphogenetic processes and the general features of the caves over the course of their history.

The present morphogenetic conditions in the caves are strongly influenced by freshwater infiltrating from the Rio Garrafo canyon, perched $\sim 50 \mathrm{~m}$ above the water table. The descending oxygen-rich freshwater has only minor influences on cave features in the vadose zone, but enhances limestone corrosion when it mixes with the thermal groundwater by the $\mathrm{H}_{2} \mathrm{~S}$ oxidation.

The data on water chemistry show that the increased freshwater recharge during floods causes the lowering of 
$\mathrm{pH}$ of the groundwater and the release of significant amount of $\mathrm{H}_{2} \mathrm{~S}, \mathrm{~S}_{2} \mathrm{O}$, and $\mathrm{CO}_{2}$ to the cave atmosphere. Due to strong air convection related to high air-water temperature differences, these gases can reach upper cave levels where they cause corrosion of the limestone or its replacement with gypsum.

The current conditions, however, originated only after the deepening of the regional base level lowered the thermal water level. In the beginning, the direct sinking of stream water was more difficult and had minor importance for the cave development. It is probable that cave development began before the Rio Garrafo reached the top of the limestone sequence, in a wholly phreatic setting, but an important step in the cave development occurred after the incision of the river canyon at the top of the limestone sequence. During this phase, some welldeveloped ascending passages testify to the flow of sulfidic water towards springs inside the canyon where travertine deposition occurred. These conditions were maintained until the present hydrogeologic setting originated.

\section{ACKNOWLEDGMENTS}

This research was partly funded by a grant from the Marche Region for the project "Speleogenetic evolution in the underground karst system of Acquasanta Terme" to the FSM (Federation of Speleological Groups of Marche Region), Istituto Italiano di Speleologia - Frasassi section, and Associazione Speleologica Acquasantana. We wish to thank Rossano Morici and the staff of the Osservatorio Geofisico di Macerata, who provided data on surface meteoric events in the study area. We also thank Jennifer Macalady for the photo in Figure 15(A) and for the useful suggestions and the help in the review of the text and we thank Fabio Baldoni for the photo in Figure 15(B).

\section{REFERENCES}

Boni, C., and Colacicchi, R., 1966, I travertini della valle del Tronto [The travertines of the Tronto Valley]: Memorie Società Geologica Italiana, v. 5 , p. $315-339$.

Crescenti, U., D’Offizzi, S., Merlino, S., and Sacchi, L., eds., 2004, Geology of Italy: Special Volume of Italian Geologic Society for the $32^{\text {th }}$ International Geologic Congress, Florence 2004, 234 p.

Farabollini, P., Gentili, B., and Materazzi, M., 2001, Freshwater travertines in the Central Apennine (Italy): Genesis and climatic and neotectonic significance, in Proceedings, International Conference on Geomorphology $5^{\text {th }}$, Tokyo, p. 8-10.

Galdenzi, S., 1997, Le grotte termali di rio Garrafo (Marche) [The thermal caves of Rio Garrafo (Marche Region, Italy], in Proceedings, Congresso Nazionale di Speleologia, 17 ${ }^{\text {th }}, 1994$, Castelnuovo Garfagnana, Italy, p. 235-238.

Galdenzi, S., 2001, L'azione morfogenetica delle acque sulfuree nelle Grotte di Frasassi, Acquasanta Terme (Appennino marchigiano Italia) e di Movile (Dobrogea - Romania) [Morphogenetic action of the sulphidic waters in the caves of Frasassi and Acquasanta Terme (Marche Apennines - Italy) and Movile (Dobrogea - Romania)]: Le Grotte d'Italia, s. V, v. 2, p. 49-61.

Galdenzi, S., and Menichetti, M., 1995, Occurrence of hypogenic caves in a karst region: Examples from central Italy: Environmental Geology, v. 26 , p. 39-47.
Galdenzi, S., Menichetti, M., and Forti, P., 1997, La corrosione di placchette calcaree ad opera di acque sulfuree: dati sperimentali in ambiente ipogeo [Limestone tablets corrosion due to sulphidic water: experimental measurements in cave environment], in Proceedings, International Congress of Speleology, $12^{\text {th }}$, Le Chaux-de-Fonds, Switzerland, v. 1, p. 187-190.

Hose, L.D., Palmer, A.N., Palmer, M.V., Northup, D.E., Boston, P.J., and DuChene, H.R., 2000, Microbiology and geochemistry in a hydrogen-sulphide-rich karst environment: Chemical Geology, v. 169, p. 399-423.

Jones, D.S., Stoffer, T.L., Lyon, E.H., and Macalady, J.L., 2006, Biogeochemistry and genomics of extremely acidic limestone-corroding cave wall biofilms: Geological Society of America Abstracts with Programs, v. 38, p. 138, A51-3.

Macalady, J.L., Jones, D.S., and Lyon, E.H., 2007, Extremely acidic, pendulous microbial biofilms from the Frasassi cave system, Italy: Environmental Microbiology, v. 9, no. 6, p. 1402-1414.

Marsili, P., and Tozzi, M., 1995, Un livello di scollamento nella dorsale di Acquasanta (AP) [A detachment level in the Acquasanta ridge (central Italy)]: Bollettino della Società Geologica Italiana, v. 114, p. $177-194$.

Madonna, R., Signanini, P., Crema, G., Di Sabatino, B., Rainone, M.L., and Di Nunzio, A., 2005, The geothermal area of Acquasanta Terme (Central Italy): Main characteristics and an attempt of field evaluation, in Proceedings, World Geothermal Congress Antalya, Turkey, p. 1-8.

Maucci, W., 1954, La Grotta termale di Acquasanta [The thermal Cave of Acquasanta], in Proceedings, Congresso Nazionale di Speleologia, $6^{\text {th }}$, p. $1-12$.

Nanni, T., 1991, Caratteri idrogeologici delle Marche [Hydrogeologic character in the Marche Region], in Regione, Marche, ed., L'ambiente fisico delle Marche [Physical environment of the Marche Region], S.E.L.C.A., Firenze, p. 115-209.

Nanni, T., and Vivalda, P., 2005, The aquifers of the Umbria-Marche Adriatic region: relationships between structural setting and groundwater chemistry: Bollettino della Società Geologica Italiana, v. 124, p. $523-542$.

Nanni, T., and Zuppi, G.M., 1986, Acque salate e circolazione profonda in relazione all'assetto strutturale del fronte adriatico e padano dell'Appennino [Salt water and deep flowpath related to structural setting of the Adriatic and Po Valley front of the Apennines]: Memorie Società Geologica Italiana, v. 35, p. 979-986.

Perrone, E., 1911, Carta idrografica d'Italia. [Hydrographic map of Italy], Ministero Industria e Commercio, Roma, $436 \mathrm{p}$.

Principi, P., 1931, Fenomeni di idrologia sotterranea nei dintorni di Triponzo (Umbria) [Subterranean hydrologic phenomena near Triponzo (central Italy)]: Le Grotte d'Italia, v. 5, p. 1-4.

Regione, Marche, ed., 1991, L'ambiente fisico delle Marche [Physical environment of the Marche Region], S.E.L.C.A., Firenze, 256 p.

Sarbu, S.M., Galdenzi, S., Menichetti, M., and Gentile, G., 2000, Geology and Biology of the Frasassi Caves in Central Italy, an ecological multidisciplinary study of a hypogenic underground ecosystem, in Wilkens, H., Culver, D.C., and Humphreys, W.F., eds., Ecosystems of the World, Subterranean Ecosystems, New York, Elsevier, p. 359-378.

Sarbu, S.M., and Kane, T.C., 1995, A subterranean chemoautotrophically based ecosystem: The National Speleological Society Bulletin, v. 57, p. 91-98.

Sarbu, S.M., Kane, T.C., and Kinkle, B.K., 1996, A chemoautotrophically based groundwater ecosystem: Science, v. 272, p. 1953-1955.

Scisciani, V., and Montefalcone, R., 2005, Evoluzione neogenico-quaternaria del fronte della catena centro-appenninica: vincoli del bilanciamento sequenziale di una sezione geologica regionale [NeogeneQuaternary evolution of the Central Apennine thrust front: constraints from sequence and forward balancing of a regional cross-section]: Bollettino della Società Geologica Italiana, v. 124, p. 579-599.

Vlasceanu, L., Sarbu, S.M., Engel, A.S., and Kinkle, B.K., 2000, Acidic, cave-wall biofilms located in the Frasassi Gorge, Italy: Geomicrobiology Journal, v. 17, p. 125-139.

Zuppi, G.M., Fontes, J.Ch., and Letolle, R., 1974, Isotopes du milieu et circulation d'eaux sulfurées dans le Latium [Environmental isotopes and sulfureos water flow in the Latium], in Proceedings, Isotope techniques in ground water hydrology Congress, International Atomic Energy Agency, Vienna, v. 1, p. $341-361$. 